\title{
Synergistic role of pipronyl butoxide in improving the Spodoptera littoralis nucleopolyhedrosis virus effectiveness against Spodoptera littoralis and studying its histopathological biosafety
}

\author{
Yasmein A. El Sayed1, Rania A. Ahmed², Shimaa M. Desoky ${ }^{3 *}$ \\ ${ }^{1}$ Plant Protection Research Institute, Agriculture Research Center, Dokki Giza, Egypt \\ ${ }^{2}$ Zoology Department, Faculty of Science, Suez University, Suez, Egypt \\ ${ }^{3}$ Botany and Microbiology Department, Faculty of Science, Suez University, Suez, Egypt
}

Received:

May 26, 2021

Accepted:

November 11, 2021

Online First:

January 12, 2022

Published:

June 06, 2022

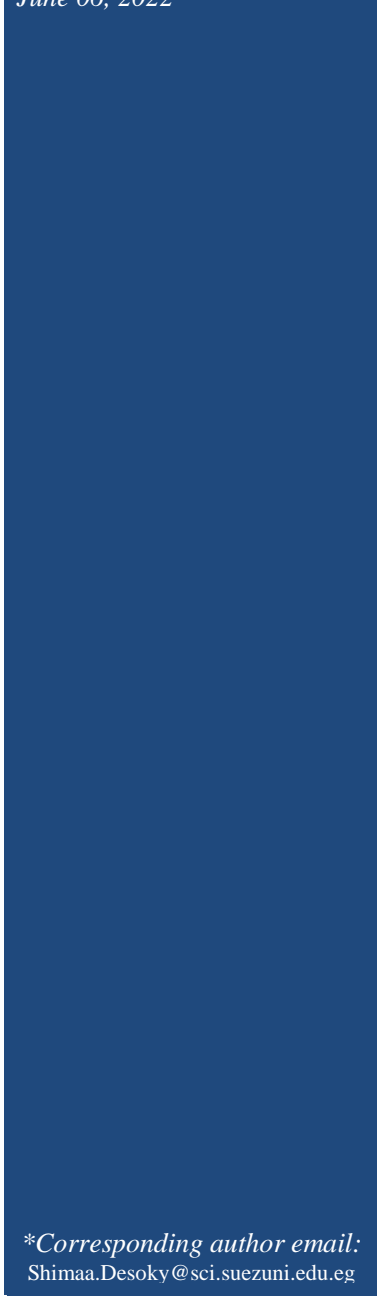

\begin{abstract}
Spodoptera littoralis nucleopolyhedrosis virus (SINPV) has been considered as a vital and safe alternative to chemical insecticides. It is effectively used in biological control of Spodoptera littoralis which is considered the most destructive and detrimental economic pest in Egypt. However, its slow speed of action limits its application among other bio-control agents. So, great attention was directed to solve this problem by using insecticide synergists. In this study the toxicity of both $S I N P V$ and the insecticide synergist pipronyl butoxide (PBO) was investigated against $2^{\text {nd }}$ and $4^{\text {th }}$ instar $S$. littoralis larvae. Different concentrations of the tested viral isolate used $\left(10^{6}, 10^{7}, 10^{8}, 10^{9}\right.$ and $\left.10^{10} \mathrm{POB} / \mathrm{ml}\right)$ showed high mortality percentage ranging from 60 to $93 \%$ and 56 to $83 \%$ for the two tested instar larvae respectively 10 days post treatment. The three PBO concentrations used $(0.1,0.2$ and $0.3 \%)$ revealed weak toxic effect as they produced 13,20 and $26 \%$ mortality rate for the three tested concentrations respectively 4 days post treatment. To examine the biosafety of the three PBO concentrations $(0.1,0.2$ and $0.3 \%)$, alone or in combination with SINPV; in vivo animal studies, and in vitro cell line studies were applied. In vivo evaluations included histomorphometric and immunohistochemical alterations in Caspase-3, Proliferating cell nuclear antigen (PCNA), tumor necrosis factor - alpha (TNF- $\alpha$ ) in hepatic and renal tissues, plus serum assessments of malondialdehyde (MDA) and total antioxidant capacity (TAC). The sulforhodamine B (SRB) cytotoxicity assay has been applied on OEC (Oral epithelial cell) and Vero (Green monkey kidney) cell lines. Results revealed that $0.1 \%$ PBO concentration was safe and didn't induce any pathogenicity, as a dose concentration - dependent decreased pathological changes by comparing $0.3 \%, 0.2 \%$ PBO treated rats . Furthermore, SlNPV was safe to rat tissues and cells and PBO didn't alter the safe nature of SINPV on mammalian cells. According to the results of histopthological bio-safety, $0.1 \%$ of PBO was applied to $4^{\text {th }}$ instar larvae for estimation its effect on larval enzyme activity and the results proved significant differences in the metabolic tested enzymes between the control and treated larvae with inhibition in both of Actylcholin esterase (AchE), Glutathione S-transferase (GST), Alpha esterases ( $\alpha$-esterases), Beta esterases (Besterases), and Glutamic oxaloacetic transaminase (GOT) and stimulation in Lactate dehydrogenase (LDH), Glutamic pyruvic transaminase (GPT) and Multi-function oxidases (MFO). Moreover, $0.1 \%$ of PBO has been mixed with viral $\mathrm{LC}_{50}$ for $2^{\text {nd }}$ and $4^{\text {th }}$ instar larvae and the results showed highly synergistic effect of PBO as 100 and $96 \%$ mortality rate respectively fourth day post treatment.
\end{abstract}

Keywords: Biological control, Nucleopolyhedrosis virus, Spodoptera littoralis, Pipronyl butoxide, Synergistic agents, Histopathological biosafety

\section{How to cite this:}

El Sayed YA, Ahmed RA and Desoky SM, 2022. Synergistic role of pipronyl butoxide in improving the Spodoptera littoralis nucleopolyhedrosis virus effectiveness against Spodoptera littoralis and studying its histopathological biosafety. Asian J. Agric. Biol. 2022(3). DOI: https://doi.org/10.35495/ajab.2021.05.227.

This is an Open Access article distributed under the terms of the Creative Commons Attribution 3.0 License. (https://creativecommons.org/licenses/by/3.0), which permits unrestricted use, distribution, and reproduction in any medium, provided the original work is properly cited. 


\section{Introduction}

The Egyptian cotton leaf worm, Spodoptera littoralis (Lepidoptera: Noctuidae) is the most destructive, serious and widespread pest not only in Egypt but also in subtropical and tropical regions (Elmenofy et al., 2020). It is known as polyphagous insect as it infests and attack various economically important crops over the year causing economical yield losses in these crops (Mohamed et al., 2019). This insect develops high level of resistance against variety of chemical insecticides (Aydin and Gürkan, 2006). In addition, the excessive use of chemical insecticides leads to harmful effect on natural enemies and all other non-target insect, also they cause detrimental problems to humans, plant and animals and induce negative impact to environment. To avoid these chemical insecticides problems, there is great interest to encourage searching for safely alternative to chemical insecticides. Many biological control agents have been used for controlling insects, such as the use of the entomopathogenic fungi, bacteria and virus.

Baculoviruses are the largest and most widely insect specific entomopathogens belonging to family Baculoviridae, they are promising alternatives to decrease dependency on deleterious chemical insecticides. They have greatest potential for use as microbial insect pest control agents against several insect pest (Lacey et al., 2015). They are safe and environmental friendly bio agents (Cheng and Lynn, 2009), also they are very specific as they infect only closely related species. Although baculoviruses infect more than 600 insect species and used successfully in controlling different insect pests (ElSalamouny et al., 2003), its use as bio-control agent is limited compared to pest control agents (Wood, 1996). Limitations to the use of baculoviruses include the cost of production, refrigerated storage and a relatively slow speed of kill (Dáder et al., 2020). Great efforts have been made to overcome these disadvantages by the synergistic combination with low concentrations of synergistic agents and using high molecular technology.

Several studies have proved that the use of synergists in addition to insecticides is considered the best option for enhancing the insecticides efficacy and for accelerating its toxic effect (Corbel et al., 2010). Synergists have a very fundamental role in increasing the efficacy of insecticide as they inhibit the natural defense of the insects by altering the insecticide detoxification enzymes (Moores et al., 2009).
Synergists also act as allosterically in which they cause changing in the shape and function of protein (enzyme) by altering the binding site and combine to point other than the chemical active site (Gunning et al., 1999). Piperonyl butoxide (PBO) was the first and most effective developed synergist. As a result of its limited toxicity to mammals, humans and birds, it is used in mixture with insecticides for household, medical and veterinary uses (Breathnach, 1998 and Keane, 1998). PBO is an organic compound used as a successful synergist and main component of pesticide formulations. Although it has no pesticide activity of its own, it enhances the effectiveness of several pesticides (Bingham et al., 2011). The prevailing situation of $\mathrm{PBO}$ among others synergists has been attributed to several factors. For example, it has been proved for its synergistic effect with a wide range of major classes of insecticides such as pyrethrins, pyrethroids, carbamates, organophosphates, and many insect growth regulators and insecticides formulation (Keane, 1998).

Farmers and farm animals are exposed to environmental pollutants including agro pesticides through ingestion, inhalation or dermally, which are then distributed through the circulation to affect different organs' tissues and cells such as liver, kidneys, lungs, and heart. Experimental animals could be used as surrogate indicators of toxic exposures, and as a tool to evaluate risk to human health and to measure the toxicity degree of substances for humans and animals (Manfo et al., 2020 and Okail et al., 2020). Liver and kidneys are largely known as the most important organs involved in detoxification of different elements, via metabolism and excretion. Agro pesticides induced Hepatotoxicity and nephrotoxicity have been illustrated by many evaluations in laboratory animals (Manfo et al., 2020). Liver and kidney damage is often accompanied by oxidative stress or inflammation (Rapa et al., 2019 and Roghani et al., 2020). This study aims to improve and develop the effect of the nucleopolyhydrosis virus on the cotton leaf worm $S$. littoralis in combination with a biosafety synergistic agent (PBO).

\section{Material and Methods}

Test organism: Laboratory strain of the Egyptian cotton leaf worm $S$. littoralis was obtained from Insect Pathogen Unit-Plant Protection Research InstituteAgriculture Research Center. The larvae were fed on 
semisynthetic diet described by Shorey and Hale (1965) and reared at $25 \pm 2^{\circ} \mathrm{C}$ and $65 \pm 5 \mathrm{RH}$ with natural photoperiod (El-Defrawi et al., 1964) under highly controlled condition to avoid any contamination.

\section{Biological insecticide: Spodoptera littoralis nucleopolyhedrosis virus (SlNPV)}

\section{Preparation of virus isolate \\ Virus isolate propagation}

Propagation of virus was carried out by inoculation of S. littoralis $3^{\text {rd }}$ instar larvae (Li and Skinner, 2005) with SlNPV isolate provided by Ahmed et al. (2016) by surface contamination of artificial diet. The inoculated larvae were distinguished every day to observe the contaminated ones based on viral disease manifestations. Infected larvae were examined preliminary by naked eye then by light microscope with Giemsa staining method according to Mustafa et al. (2001) for detection of viral occlusion bodies (VOBs) . After the observation, the contaminated larvae were collected and preserved in $-20^{\circ} \mathrm{C}$ till purification of VOBs.

\section{Viral occlusion bodies (VOBs) purification}

VOBs were purified by using Sudhakar et al. (1997) method with slight modification. Infected larvae showing virus infection symptoms were transported to micro centrifuge tube and homogenized in $300 \mu 1$ distilled water. The homogenate was filtered through chess cloth and subjected to $60 \% \mathrm{wt} / \mathrm{vol}$ sucrose layer then centrifuged at $10000 \mathrm{rpm}$ for $30 \mathrm{~min}$. VOBs formed band on the top of the layer, this band was collected and subjected to $40 \%$ wt/vol sucrose layer and centrifuged at $10000 \mathrm{rpm}$ for $30 \mathrm{~min}$. VOBs band which again formed near the bottom of the filtrate was collected and washed with distilled water. All previous steps were done at $4^{\circ} \mathrm{C}$. Purified VOBs were suspended in distilled water and stored at $-20^{\circ} \mathrm{C}$. Then the confirmation of purification effectiveness method caused by making OBs slide and examined under light microscope by Giemsa staining method according to Mustafa et al. (2001). The concentration of $\mathrm{VOBs} / \mathrm{ml}$ was determined by counting their number using Neubaur Hemocytometer (Alves and Moraes, 1998). Five concentrations were prepared from VOBs mother suspension by serial dilution to be used in toxicity experiment.

\section{Toxicity test}

Five $S l$ NPV concentrations $\left(10^{10}, 10^{9}, 10^{8}, 10^{7}\right.$ and
$10^{6} \mathrm{POB} / \mathrm{ml}$ ) were tested against $2^{\text {nd }}$ and $4^{\text {th }}$ instar larvae. The experiment was conducted in plastic cups containing semisynthetic diet by applying diet surface treatment procedure (Addy, 1969), in which $250 \mu 1$ of the virus suspension was pipetted on the semisynthetic diet surface, distributed then left to dry. The virus suspension was replaced by distilled water in the control treatment. Larvae of $2^{\text {nd }}$ and $4^{\text {th }}$ instar were allowed to feed on treated diet for 48 hour then transfer to clean cup contain untreated diet. Three replicates each of ten larvae per virus concentration plus three replicates for control were used. All treatments were incubated at $25^{\circ} \mathrm{C}, 60-70 \%$ $\mathrm{RH}$ and the larval mortality was recorded at two days for a period of ten days. The mortality percentage and lethal concentration $\left(\mathrm{LC}_{50}\right)$ were calculated according to Finney (1971) using Ldp line software (Bakr, 2000).

\section{Synergistic material: Pipronyl butoxide (PBO)}

Piperonyl butoxide (99\%) was purchased from Sigma-Aldrich Company as oil and solved in analytical grade acetone to prepare its tested concentrations (Huang et al., 2010).

\section{Pipronyl butoxide toxicity test}

Concentrations of $0.1,0.2$ and $0.3 \%$ were prepared from PBO by using analytical grade acetone for testing their toxicity against $S$. littoralis $2^{\text {nd }}$ and $4^{\text {th }}$ instar larvae according to Diab (2011) with slight modification. The two tested instar were placed in cups containing treated artificial diet with PBO and allowed to feed for 48 hour, then transferred to clean cups containing untreated diet and observed daily. Thirty larvae for PBO concentration plus 30 larvae treated with acetone only as a control were replicated 3 times. Larval mortality was listed after 24 hours till 96 hours (Radova, 2010).

\section{Histopathological evaluations of SlNPV and PBO biosafety \\ Animals}

Fifty- six adult male Sprague-Dawley rats weighing $162 \pm 13 \mathrm{~g}$ were used in the present experiment. Rats were brought from the National Research Center (NRC), Giza, Egypt, and then housed in plastic cages (7 rats/cage) at normal atmospheric temperature (26 $\pm 3{ }^{\circ} \mathrm{C}$ ) with normal 12-h light/dark cycle. Diet and water were provided ad libitum. Rats were allowed to be acclimatized for one week prior to experimental use to exclude any infection.

All experimental animal studies were approved by 
Suez university research ethics committee

Experimental design: Animals were divided into 8 groups as following

Group I: The normal control group.

Group II: Rats were given a single oral dose of SlNPV $1 \times 10^{5}$ PIB (1ml/100gm body weight).

Group III: Piperonyl butoxide (PBO) group, this group was subdivided into 3 subgroups, in each of which rats were given a single oral dose of $\mathrm{PBO}$ as 0.1 . 0.2 , or $0.3 \% \mathrm{mg} / \mathrm{kg} \mathrm{b.w}(1 \mathrm{ml} / 100$ gm b.w $)$.

Group IV: $\mathrm{PBO}+$ SINPV group, this group was subdivided into 3 subgroups, in each of which rats were given $\mathrm{PBO}$ as $0.1,0.2$, or $0.3 \% \mathrm{mg} / \mathrm{kg} \mathrm{b} . \mathrm{w}+\mathrm{a}$ single oral dose of SINPV 1x $10^{5}$ PIB.

All animals were observed for 21 days after all treatments, and then were sacrificed by cervical dislocation, dissected out and then their livers and kidneys were removed and were cut into small pieces. Liver and kidneys specimens were fixed in $10 \%$ neutral formalin, dehydrated, cleared in xylene and embedded in paraffin wax for histological and immunohistochemical examinations. Moreover, sera were obtained for biochemical analyses.

\section{Histological and morphometric examinations}

Sections of $5 \mu \mathrm{m}$ thickness were stained with hematoxylin and eosin (Drury and Wallington, 1980). The criteria for scoring liver injury depended on vacuolization and pyknosis of hepatocytes, activation of Kupffer cells and sinusoids enlargement. Injury of kidney tissue was evaluated depending on degeneration of Bowman capsules, glomeruli, proximal and distal tubules, in addition to, vascular congestion and interstitial edema. Five nonoverlapped fields from each specimen (X400) was examined to score liver and kidney histomorphometric alterations. Histopathological scoring of each specimen was done via a scale ranging from 0 - 3 ( 0 : none, 1 : mild, 2 : moderate, and 3: severe) for each criterion. The total score was 9 for both liver and kidney tissues (Ibrahim et al., 2010).

\section{Immunohistochemical examination}

For immunohistochemical localization, $4 \mu \mathrm{m}$ thickness paraffin sections were stained by using the avidin-biotin peroxidase method. Sections were incubated with primary antibody for $60 \mathrm{~min}$ for each of:

1- Caspase-3 according to Jackson et al. (2008).

2- Proliferating cell nuclear antigen (PCNA) immunoreactivity was performed according to Eldridge and Goldsworthy (1996).
3- TNF- $\alpha$ was prepared according to Orfila et al. (1998).

Then slides were incubated with a biotinylated secondary antibody, then incubated with horseradish peroxidase conjugated with streptavidin for further $15 \mathrm{~min}$, followed by adding 3-amino-9ethylcarbasole (Dako Cytomation, USA).

\section{Image analyses}

Semi-quantitative scoring system (Image $\mathbf{J}$ software, Java based application for analyzing images) was used to analyze digital images. The immunohistochemical-stained sections were analyzed in 10 microscopic fields under high-power field (X400) microscope to calculate each of the following:

a. The degree of reaction of Capase 3 and TNF- $\alpha$ area were recorded. Percentage of positive stained area (\%) was calculated as mean of 10 fields/slide.

b. PCNA-Labeling Index (PCNA-LI):

Randomly, five microscopic fields per slide were chosen. The PCNA-LI for each field was evaluated as a percentage of immuno-labeled cells to all basal cells. For each section, the mean \pm SD was calculated (Abdel-Dayem, 2009).

c. Calculation of Apoptotic index (AI) $(\%)$ :

$\mathrm{AI}=$ (number of apoptotic cells/the total number of counted cells $) \times 100 \%$.

\section{Biochemical studies}

Sera were obtained through blood samples centrifugation, and then stored at $-20^{\circ} \mathrm{C}$ until using to estimate the following parameters:

1-The lipid peroxidation marker, malondialdhyde (MDA) according to Ohkawa et al. (1979).

2- The total anti-oxidant capacity (TAC) according to Sedlak and Lindsay (1968).

Cell culture Sulforhodamine B (SRB) cytotoxicity assay For more confirmation of cytotoxic effects of PBO different concentrations used in the presented study, the effect of PBO on cell viability by SRB assay to evaluate the growth inhibition colorimetrically, as the cell numbers is evaluated indirectly by staining total cellular protein with SRB dye according to Skehan et al. (1990). SRB assay was applied on two different cell lines OEC (Oral epithelial cell) and Vero (Green monkey kidney). Cell lines were obtained from Nawah Scientific Inc., (Mokatam, Cairo, Egypt). Cells were maintained in DMEM media supplemented with $100 \mathrm{mg} / \mathrm{mL}$ of streptomycin, 100 units $/ \mathrm{mL}$ of penicillin 
and $10 \%$ of heat-inactivated fetal bovine serum in humidified, $5 \%(\mathrm{v} / \mathrm{v}) \mathrm{CO}_{2}$ atmosphere at $37^{\circ} \mathrm{C}$.

\section{Synergistic effect of PBO}

According to PBO toxicity test and histopathological evaluation of SINPV and PBO biosafety studies, $0.1 \%$ PBO concentration was used for examination its effect on $S$. littoralis detoxification enzymes and synergistic potential toward SINPV in vitro.

\section{Estimation of enzymes activities}

The $4^{\text {th }}$ instar larvae were allowed to feed on treated artificial diet with PBO for $1 \mathrm{~h}$ for detection the disruption the detoxification enzymes (Dadzie et al., 2017), then collected and frozen in $-20^{\circ} \mathrm{C}$ till enzymes estimation test.

\section{Sample preparation}

Treated $4^{\text {th }}$ instar larvae were homogenized in distilled water $(50 \mathrm{mg} / 1 \mathrm{ml})$. Homogenates were centrifuged at $8000 \mathrm{rpm}$ for $15 \mathrm{~min}$ at $5^{\circ} \mathrm{C}$ in a refrigerated centrifuge. The deposits were discarded and the supernatants were kept in a deep freezer till use.

\section{Estimated enzymes}

\section{Acetylcholinesterase (AchE)}

AchE activity was measured according to the method described by Simpson et al. (1964) using acetylcholine bromide $(\mathrm{AchBr})$ as substrate.

\section{Glutathione S-transferase (GST)}

GST catalyzes the conjugation of reduced glutathione with 1-chloro2,4-dinitrobenzene (CDNB) via the $-\mathrm{SH}$ group of glutathione. The conjugate, $\mathrm{S}$ (2, 4-dinitro-phenyl)-L- glutathione could be detected as described by Habig et al. (1974).

\section{Lactate dehydrogenase (LDH)}

LDH activity was determined according to the method derived from the formulation recommended by the German Society for clinical chemistry (Deutsche Gesellschaft Fur Klinische Chemie) (DGKC, 1972).

Oxidase Oxidase activity was determined according to Hansen and Hodgson, (1971) with slight modification.

\footnotetext{
Alpha esterases ( $\alpha$-esterases) and Beta esterases (Besterases)

$\alpha$-esterases and B- esterases were determined according to Van Asperen (1962).
}

Glutamic pyruvic transaminase (GPT) and Glutamic oxaloacetic transaminase (GOT)

GPT and GOT were determined according to the method of Reitman and Frankel (1957).

\section{Synergistic assay of PBO with $\mathrm{SlNPV} \mathrm{LC}_{\mathbf{5 0}}$}

Viral $\mathrm{LC}_{50}$ calculated previously was tested individually against two tested instar larvae and the mortality rate recorded daily and also combined to $0.1 \%$ PBO with volume ratio 1:1 then pipetted and distributed on the artificial diet. The treated artificial diet was introduced to $2^{\text {nd }}$ and $4^{\text {th }}$ instar larvae for 48 hours then replaced by untreated diet. Acetone was applied as a control. All treatments were kept at a constant temperature $30^{\circ} \mathrm{C}$ and larval mortality was recorded daily.

\section{Statistical analysis}

Statistical analysis was performed using SPSS v.16. Results were calculated as mean \pm standard deviation (SD) and all statistical comparisons were made by means of one-way ANOVA test followed by Duncan's multiple range test post hoc analysis. A P value $(\mathrm{P}>0.01)$ considered significant.

\section{Results}

External symptoms of insect infestation with $S I N P V$ Infected larvae were examined by naked eye showing that they were smaller than normal one, slow motion, pale and milky color cuticle, swollen larval body and Liquefied larvae releasing millions of VOBs to the environment (Fig .1)

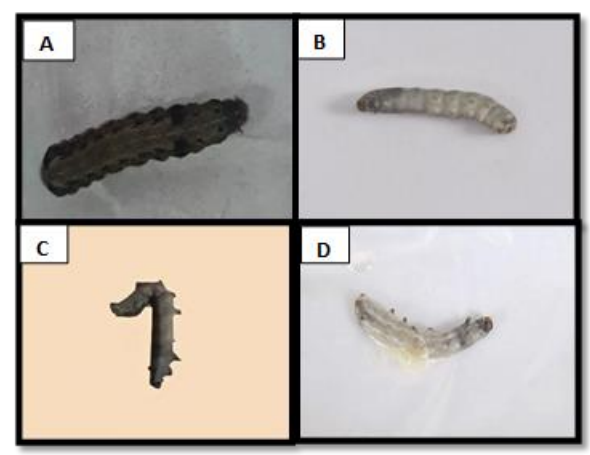

Figure-1: Untreated larvae (A) and Viral symptoms of infected $S$. littoralis showing, Pale and milky color cuticle (B), Swollen larval body (C), Liquefied larvae (D).

\section{VOBs Light microscope observation}

After virus propagation and purification, the presence of VOBs as polyhedral and negative stain particles was confirmed under light microscope (Fig.2) 


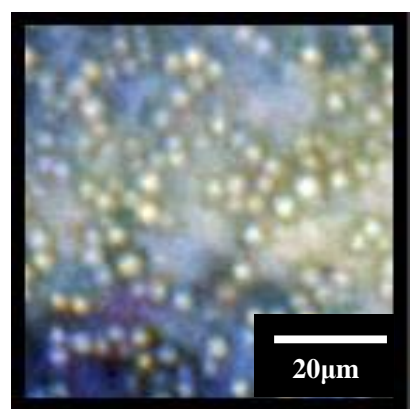

Figure-2: $S l N P V$ occlusion bodies under Light microscope.

\section{Toxicity test of $S l N P V$}

The results obtained from toxicity test of SINPV against $2^{\text {nd }}$ and $4^{\text {th }}$ instar larvae of $S$. littoralis (Table $1 \& 2$ and Fig. 3\&4) demonstrated that larval mortality was directly proportional to viral concentration and time elapsed post treatment. The high viral concentration used $10^{10} \mathrm{PIB} / \mathrm{ml}$ caused $93 \%$ which is considered the maximum mortality rate for $2^{\text {nd }}$ instar larvae, and $83 \%$ for $4^{\text {th }}$ instar larvae after 10 days post treatment. The remaining concentrations produced mortality percentage ranged from $60-83 \%$ and $56-77 \%$ for $2^{\text {nd }}$ and $4^{\text {th }}$ instar larvae respectively. It is clear from the data that $2^{\text {nd }}$ instar larvae were more susceptible to all tested concentrations than $4^{\text {th }}$ instar ones.

Table-1: Toxicity of $S l N P V$ against $2^{\text {nd }}$ instar larvae of $S$. littoralis.

\begin{tabular}{|c|c|c|c|c|c|}
\hline \multirow{2}{*}{$\begin{array}{c}\text { Concentrati } \\
\text { on (PIB/ml) }\end{array}$} & \multicolumn{5}{|c|}{$\mathbf{2}^{\text {nd }}$ instar larvae } \\
\cline { 2 - 6 } & 2 days & 4 days & 6 days & 8 days & 10 days \\
\hline $1.2 \times 10^{6}$ & 3 & 16 & 30 & 46 & 60 \\
\hline $1.2 \times 10^{7}$ & 6 & 26 & 36 & 53 & 66 \\
\hline $1.2 \times 10^{8}$ & 11 & 30 & 43 & 60 & 76 \\
\hline $1.2 \times 10^{9}$ & 23 & 36 & 51 & 66 & 90 \\
\hline $1.2 \times 10^{10}$ & 30 & 43 & 60 & 80 & 93 \\
\hline $\mathrm{LC}_{50}$ & $\begin{array}{c}2.3 \times 10 \\
11\end{array}$ & $\begin{array}{c}7.0 \\
\times 10^{10}\end{array}$ & $6.3 \times 10^{8}$ & $\begin{array}{c}4.5 \times \\
10^{6}\end{array}$ & $2.9 \times 10^{5}$ \\
\hline
\end{tabular}

Table-2: Toxicity of $S I N P V$ against $4^{\text {th }}$ instar larvae of $S$. littoralis.

\begin{tabular}{|c|c|c|c|c|c|}
\hline \multirow{2}{*}{$\begin{array}{c}\text { Concentr } \\
\text { ation } \\
(\mathbf{P I B} / \mathrm{ml})\end{array}$} & \multicolumn{5}{|c|}{$\mathbf{4}^{\text {th }}$ instar larvae } \\
\cline { 2 - 6 } & $\begin{array}{c}2 \\
\text { days }\end{array}$ & 4 days & 6 days & $\begin{array}{c}8 \\
\text { days }\end{array}$ & 10 days \\
\hline $1.2 \times 10^{6}$ & 3 & 10 & 20 & 40 & 56 \\
\hline $1.2 \times 10^{7}$ & 3 & 16 & 26 & 46 & 63 \\
\hline $1.2 \times 10^{8}$ & 10 & 23 & 30 & 53 & 70 \\
\hline $1.2 \times 10^{9}$ & 16 & 26 & 36 & 56 & 77 \\
\hline $1.2 \times 10^{10}$ & 23 & 33 & 46 & 66 & 83 \\
\hline $\mathrm{LC}_{50}$ & $\begin{array}{c}1.8 \times \\
10^{12}\end{array}$ & $\begin{array}{c}1.2 \\
\times 10^{12}\end{array}$ & $\begin{array}{c}6.0 \times \\
10^{10}\end{array}$ & $\begin{array}{c}2.0 \times \\
10^{7}\end{array}$ & $\begin{array}{c}7.0 \\
\times 10^{5}\end{array}$ \\
\hline
\end{tabular}

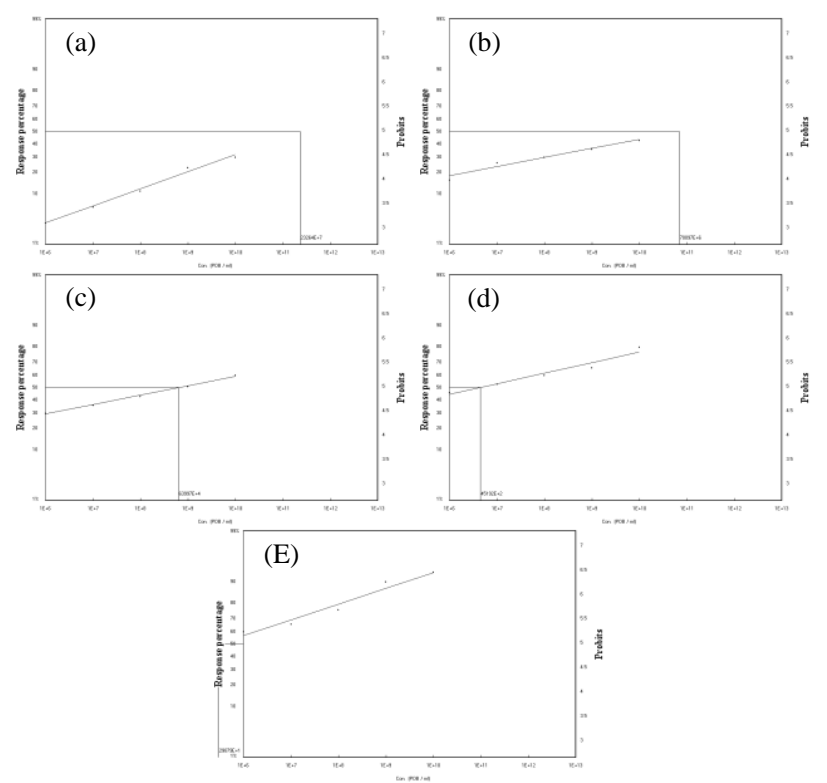

Figure-3: Toxicity regression lines of $S$. littoralis $2^{\text {nd }}$ instar larvae treated with $S l N P V$, after (A) 2 days, (B) 4 days, (C) 6 days, (D) 8 days and (E) 10 days.
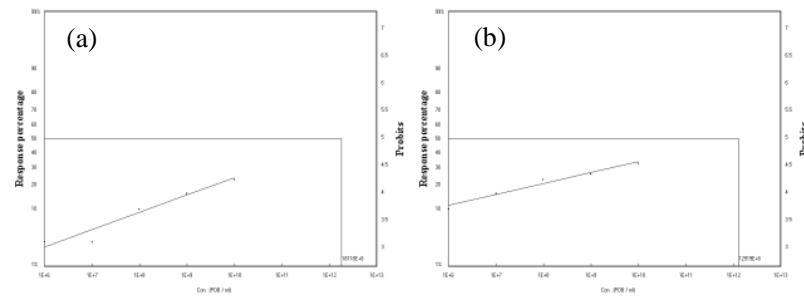

(c)

(d)
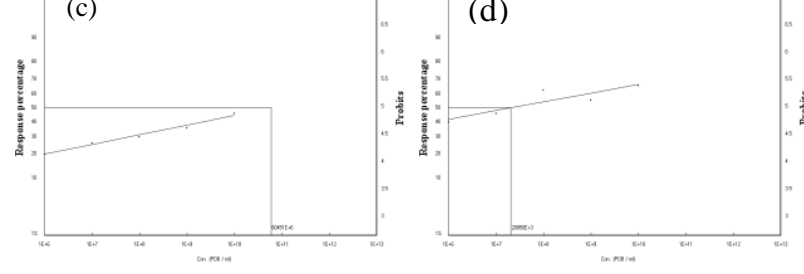

(E)

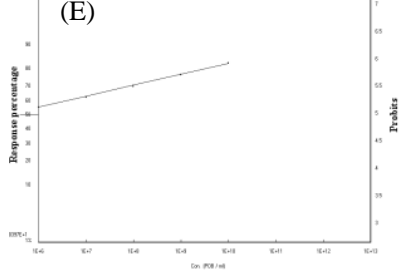

Figure-4: Toxicity regression lines of $S$. littoralis $4^{\text {th }}$ instar larvae treated with $S I N P V$ after (A) 2 days, (B) 4 days, (C) 6 days, (D) 8 days and (E) 10 days.

\section{Toxicity and synergistic effect of PBO}

Mortality percentage achieved by the three tested PBO concentrations used $(0.1,0.2$ and $0.3 \%)$ was $(6,10$ and 
$16 \%)$ and $(0,6$ and $13 \%)$ for $2^{\text {nd }}$ and $4^{\text {th }}$ instar larvae respectively recorded after 24 hour and reached to (16, 23 and $33 \%)$ and $(13,20$ and $26 \%)$ for $2^{\text {nd }}$ and $4^{\text {th }}$ instar larvae respectively after 4 day post treatment (Table 3 ). While the mortality percentage achieved by mixture of PBO and SlNPV LC Lo $_{50}$ was $(36,66,90,100$ $\%)$ and $(30,53,80,96 \%)$ against $2^{\text {nd }}$ and $4^{\text {th }}$ instar larvae of $S$. littoralis respectively after 1, 2, 3 and 4 days (Table 4 and Fig. 5)

Table-3: Toxicity of PBO against $2^{\text {nd }}$ and $4^{\text {th }}$ instar larvae of $S$. littoralis after $1,2,3$ and 4 days post treatment.

\begin{tabular}{|c|c|c|c|c|c|c|c|c|}
\hline \multirow{3}{*}{$\begin{array}{l}\text { Concentr } \\
\text { ation (\%) }\end{array}$} & \multicolumn{8}{|c|}{ Mortality Percentage (\%) } \\
\hline & \multicolumn{2}{|c|}{1 day } & \multicolumn{2}{|c|}{2 day } & \multicolumn{2}{|c|}{3 day } & \multicolumn{2}{|c|}{4 day } \\
\hline & $\begin{array}{l}2^{\text {nd }} \\
\text { instar }\end{array}$ & $\begin{array}{l}4^{\text {th }} \\
\text { instar }\end{array}$ & $\begin{array}{l}2^{\text {nd }} \\
\text { instar }\end{array}$ & $\begin{array}{l}4^{\text {th }} \\
\text { instar }\end{array}$ & $\begin{array}{l}2^{\text {nd }} \\
\text { instar }\end{array}$ & $\begin{array}{l}4^{\text {th }} \\
\text { instar }\end{array}$ & $\begin{array}{l}2^{\text {nd }} \\
\text { instar }\end{array}$ & $\begin{array}{l}4^{\text {th }} \\
\text { instar }\end{array}$ \\
\hline 0.1 & 6 & 0 & 10 & 6 & 13 & 10 & 16 & 13 \\
\hline 0.2 & 10 & 6 & 16 & 10 & 20 & 13 & 23 & 20 \\
\hline 0.3 & .16 & 13 & 23 & 20 & 30 & 26 & 33 & 26 \\
\hline
\end{tabular}

Table-4: Toxicity of PBO, SlNPV $\mathrm{LC}_{50}$ and mixture of PBO and $S l N P V \mathrm{LC}_{50}$ against $2^{\text {nd }}$ and $4^{\text {th }}$ instar larvae of $S$. littoralis after $1,2,3$ and 4 days post treatment.

\begin{tabular}{|c|c|c|c|c|c|c|c|c|c|c|c|c|}
\hline \multirow[b]{3}{*}{$\begin{array}{c}\text { Trea } \\
\text { ted } \\
\text { insta } \\
r\end{array}$} & \multicolumn{12}{|c|}{ Mortality percentage (\%) } \\
\hline & \multicolumn{3}{|c|}{1 day } & \multicolumn{3}{|c|}{2 day } & \multicolumn{3}{|c|}{3 day } & \multicolumn{3}{|c|}{4 day } \\
\hline & $\begin{array}{c}\mathrm{PB} \\
\mathrm{O}\end{array}$ & $\begin{array}{l}\text { Vir } \\
\text { us }\end{array}$ & $\begin{array}{l}\text { PB } \\
\text { O+ } \\
\text { Vir } \\
\text { us }\end{array}$ & $\begin{array}{c}\text { PB } \\
O\end{array}$ & $\begin{array}{l}\text { Vir } \\
\text { us }\end{array}$ & $\begin{array}{l}\text { PB } \\
\mathrm{O}+ \\
\text { Vir } \\
\text { us } \\
\end{array}$ & $\begin{array}{c}\text { PB } \\
\mathrm{O}\end{array}$ & $\begin{array}{l}\text { Vir } \\
\text { us }\end{array}$ & $\begin{array}{l}\mathrm{PB} \\
\mathrm{O}+ \\
\text { Vir } \\
\text { us }\end{array}$ & $\begin{array}{c}\text { PB } \\
\mathrm{O}\end{array}$ & $\begin{array}{l}\text { Vir } \\
\text { us }\end{array}$ & $\begin{array}{l}\text { PB } \\
\text { O+ } \\
\text { Vir } \\
\text { us }\end{array}$ \\
\hline $\begin{array}{l}2^{\text {nd }} \text { in } \\
\text { star }\end{array}$ & 6 & 0 & 36 & 10 & 3 & 66 & 13 & 6 & 90 & 16 & 10 & 100 \\
\hline $\begin{array}{l}4^{\text {th }} \text { in } \\
\text { star }\end{array}$ & 0 & 0 & 30 & 6 & 3 & 53 & 10 & 3 & 80 & 13 & 6 & 96 \\
\hline
\end{tabular}

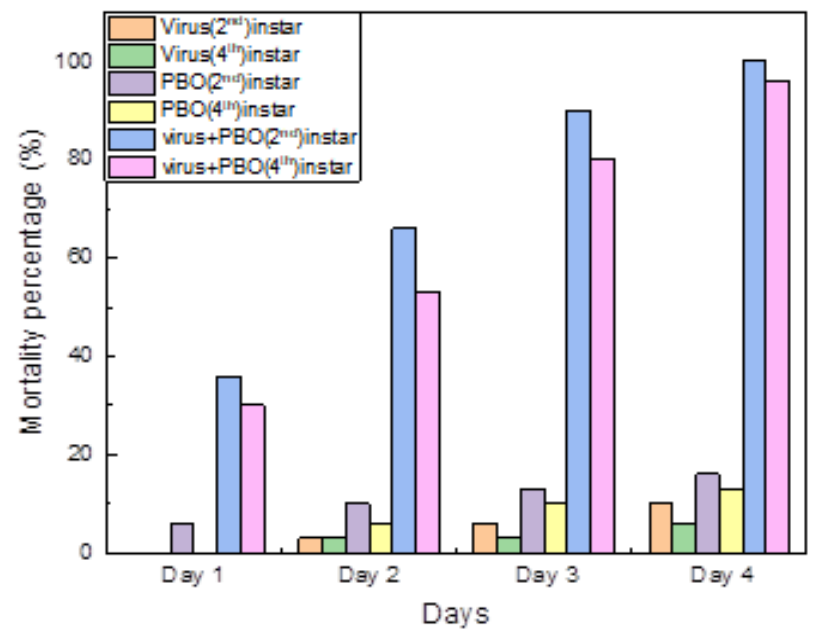

Fig. (5) Comparison between Toxicity of PBO, SINPV LC50 and mixture of PBO and SINPV LC50 against 2nd and 4th instar larvae of $S$. littoralis after 1, 2, 3 and 4 days.

\section{Estimation of enzymes activities}

The activities of AchE, GST, LDH, GOT, GPT, MFO, $\alpha$ - esterase and $\beta$ - esterase of $S$. littoralis treated with $0.1 \%$ of $\mathrm{PBO}$ were assayed and differences in the metabolic enzyme activities between the control and treated larvae were illustrated in Table 5, $6 \& 7$. The mean level of all enzymes were significantly lower than control except GPT, MFO and LDH. The activity ratio for these enzymes were $0.41,0.71,1.40,0.99,1.63,1.26,0.84$ and 0.85 respectively.

Table-5: Effect of PBO on AchE, GST and LDH activities of $4^{\text {th }}$ instar larvae of $S$. littoralis.

\begin{tabular}{|c|c|c|c|c|c|c|}
\hline Treatment & $\begin{array}{c}\text { AchE } \\
\text { Mean } \pm \\
\text { SE }\end{array}$ & $\begin{array}{l}\text { Activit } \\
\text { y ratio }\end{array}$ & $\begin{array}{c}\text { GST } \\
\text { Mean } \pm \\
\text { SE }\end{array}$ & $\begin{array}{c}\text { Activity } \\
\text { ratio }\end{array}$ & $\begin{array}{c}\text { LDH } \\
\text { Mean } \pm \\
\text { SE }\end{array}$ & $\begin{array}{c}\text { Activity } \\
\text { ratio }\end{array}$ \\
\hline PBO & $\begin{array}{c}92.86 \pm \\
3.05 \\
\end{array}$ & \multirow[b]{2}{*}{0.41} & $\begin{array}{c}72.66 \pm \\
2.49\end{array}$ & \multirow[b]{2}{*}{0.71} & $\begin{array}{l}672 \pm \\
67.27 \\
\end{array}$ & \multirow[b]{2}{*}{1.40} \\
\hline Control & $\begin{array}{l}226 \pm \\
13.36\end{array}$ & & $\begin{array}{c}101 \pm \\
2.94\end{array}$ & & $\begin{array}{l}477.66 \\
\pm 13.57\end{array}$ & \\
\hline
\end{tabular}

Table-6: Effect of PBO on GOT, GPT and Multifunction oxidases (MFO) activities of $4^{\text {th }}$ instar larvae of $S$. littoralis.

\begin{tabular}{|c|c|c|c|c|c|c|}
\hline Treatment & $\begin{array}{c}\text { GOT } \\
\text { Mean } \pm \\
\text { SE }\end{array}$ & $\begin{array}{l}\text { Activit } \\
\text { y ratio }\end{array}$ & $\begin{array}{c}\text { GPT } \\
\text { Mean } \pm \\
\text { SE }\end{array}$ & $\begin{array}{c}\text { Activity } \\
\text { ratio }\end{array}$ & $\begin{array}{c}\text { MFO } \\
\text { Mean } \pm \\
\text { SE }\end{array}$ & $\begin{array}{l}\text { Activit } \\
\text { y ratio }\end{array}$ \\
\hline PBO & $\begin{array}{c}1335.66 \\
\pm 7.40 \\
\end{array}$ & \multirow{2}{*}{0.99} & $\begin{array}{c}1594.66 \\
\pm 75.21 \\
\end{array}$ & \multirow{2}{*}{1.63} & $\begin{array}{c}34.03 \pm \\
0.74\end{array}$ & \multirow{2}{*}{1.26} \\
\hline Control & $\begin{array}{r}1348.66 \\
\pm 11.46\end{array}$ & & $\begin{array}{c}973.33 \pm \\
29.63\end{array}$ & & $\begin{array}{c}26.86 \pm \\
0.89\end{array}$ & \\
\hline
\end{tabular}

Table-7: Effect of PBO on $\alpha$ - estearase and $\beta$ - esterase activities of $4^{\text {th }}$ instar larvae of $S$. littoralis.

\begin{tabular}{|c|c|c|c|c|}
\hline Treatment & $\begin{array}{c}\alpha \text { - esterase } \\
\text { Mean } \pm \text { SE }\end{array}$ & $\begin{array}{c}\text { Activity } \\
\text { ratio }\end{array}$ & $\begin{array}{c}\beta \text { - esterase } \\
\text { Mean } \pm \text { SE }\end{array}$ & $\begin{array}{c}\text { Activity } \\
\text { ratio }\end{array}$ \\
\hline $\mathrm{PBO}$ & $\begin{array}{c}1080 \pm \\
16.33\end{array}$ & 0.84 & $775 \pm 17.68$ & 0.85 \\
\hline
\end{tabular}

Histological and histomorphometric Results

Figure (6) and table (8) show histological and morphometric changes in liver and kidney tissues among experimental groups. Microscopic examinations of liver and kidney $\mathrm{H} \& \mathrm{E}$ stained section revealed that no considerable histopathological alterations or injury score in liver and kidney tissues were detected when comparing control group with SlNPV treated rats, which indicates the infectivity of SlNPV on liver and kidney. Histological examination of liver parenchyma of both control group and SINPV treated group revealed a normal liver histoarchitecture with arranged hepatocytes in hepatic cords surrounding the central vein and separated by free sinusoids. The 
sinusoids were lined with endothelium containing phagocytic Kupffer cells. Each individual hepatocyte was polyhedral in shape with central rounded nucleus, where some hepatocytes were binucleated. kidney sections of both control group and SINPV treated group showed the typical structure of the renal corpuscles and tubules as SINPV treated rats did not show any histological changes by comparing with control group (Figs 6a : 6d). Treating rats with the PBO in three different doses led to the progression of histopathological changes in a direct relation between the high concentration of the $\mathrm{PBO}$ and the severity of histopathological changes in both kidney and liver tissues. Rats treated with PBO at dose levels $0.3 \%$ induced marked histopathological alterations and significant increase in injury score in liver and kidney when compared with control group and $0.2 \%, 0.1 \%$ treated groups. liver tissues revealed leucocytic infiltration, blood venues congestion and cytoplasmic vaculation. Hemorrhagic foci, necrotic cells with pyknotic nuclei were also observed. Fatty degeneration was observed markedly. Moreover, it was also noted that, animals co-treated with $0.3 \%$ PBO plus SINPV didn't reveal any difference when compared with rats treated with $0.3 \%$ PBO alone. Examination of renal tissues of $0.3 \%$ PBO treated rats showed periglomerular and interstitial necrosis associated with inflammatory cells infiltration. Congested blood vessels and interstitial hemorrhage, tubular degeneration and vaculation were abundant, glomerular atrophy, widening in Bowman's capsule and tubular dilatation. There was the same degree of histopathological changes in the parallel group that dual treated with $0.3 \%$ PBO plus SlNPV, without much difference (Figs 6e: 6h). liver and kidney tissues of rats treated with $0.2 \% \mathrm{PBO}$, and $0.2 \% \mathrm{PBO}$ plus SINPV showed marked improvement in both liver and kidney tissues architecture, in addition to, a marked decrease of injury score in liver and kidney when compared with $0.3 \%$ PBO, and $0.3 \%$ PBO plus SlNPV respectively, as the degenerative changes were markedly declined, but the liver tissues still displaying vaculation and fatty degeneration, while a mild leucocyte infiltration and vaculation in kidney tissue (Figs 6i : 6L). Continuing the dose dependent gradual improvement, microscopic examinations of $0.1 \%$ PBO, and $0.1 \%$ PBO plus SINPV(showed advanced degree of improvement of liver and kidney tissues, and injury score as hepatocytes rearranged in radiating strands, showing normal nuclei and cytoplasm which didn't include any water vacuoles or fat droplets . Moreover, kidney tissues returned to the classical appearance as corpuscles and tubules appeared more or less normal like when compared with control animals (Figs. 6m: 6P) . The histopathological alterations in different animal groups were summarized in table (8).

Fig.(6) The histopathological changes in liver and

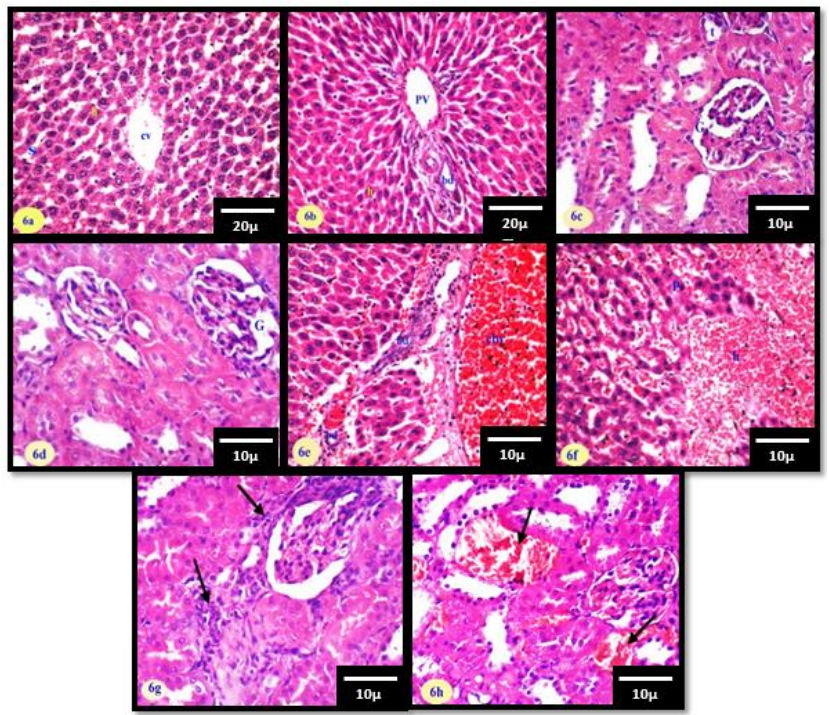

kidney sections among different experimental groups ( $H$ and $E, X 400$ ). (6a) Liver section from a control rat showing normal hepatic histoarchitecture with normal hepatocytes (h), sinusoid (s) and vascular channels as central vein (cv). (6b) Liver section of SINPV treated rat showing normal hepatic tissue with normal portal area with normal appearance of portal vein (pv), and bile duct (bd). (6c) Kidney tissue of control rat showing the classic histological structure of renal tissue with normal glomeruli $(G)$ and tubules $(t)$. (6d) Kidney section of rat from SINPV group showing the normal histological appearance of renal parenchyma. (6e) Liver section from $0.3 \%$ PBO treated rat showing severe dilated congested blood vessel (cbv), and proliferated bile duct (bd). (6f) Liver section of $0.3 \%$ PBO + SINPV treated rat showing severe hemorrhage (h) with pyknotic nuclei (p) and dilated sinusoid filled with RBC(s). (6g) Kidney section from rat treated with $0.3 \%$ PBO showing periglomerular andinterstitial necrosis associated with inflammatory cells infiltration (arrows). (6h) Kidney section of a rat treated with $0.3 \%$ PBO + SINPV showing congestion of renal blood vessels (arrows). 


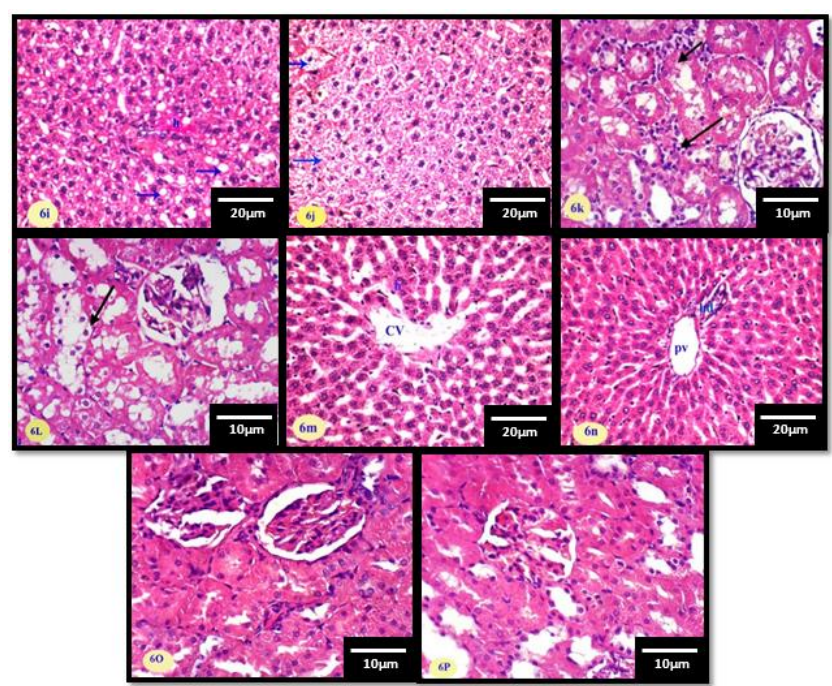

Fig. 6: (6i) Liver section of a rat treated with $0.2 \%$ PBO showing fatty degenerative changes (arrows) in some hepatocytes and limited hemorrhage (h). (6j) Liver section from $0.2 \%$ PBO + SINPV treated rat showing severe vacuolated hepatocytes (arrows) with pyknotic nuclei. (6k) Kidney section of $0.2 \%$ PBO treated rat showing slight vaculation of epithelial lining some renal tubules and intertubular few inflammatory cells infiltration (arrows). (6L) Kidney section of $0.2 \%$ PBO + SINPV treated rat showing vaculation of epithelial lining renal tubules (arrow). (6m) Liver section taken from $0.1 \%$ PBO treated rat showing normal architecture with normal appearance of hepatocytes (h), sinusoid (s) and vascular channels as central vein (cv). (6n) liver section taken from $0.1 \%$ PBO + SINPV showing normal architecture of portal area with normal appearance of portal vein (pv), and bile duct (bd). (6o) Kidney section of rat from $0.1 \%$ PBO treated group showing normal renal tissue with no histopathological changes. (6p) Kidney section of a rat from 0.1\% PBO + SINPV treated group showing no histopathological changes in renal tissue.

\section{Immunohistochemical Results}

i. Capase3 Immunoexpression

Immunohistochemical examinations of livers and kidneys sections of control and SINPV-treated rats show negative immunoreactivity of Caspase-3. Rats treated with $0.3 \% \mathrm{PBO}$, or $0.3 \%$ PBO plus SINPV revealed a significant increase in Caspase-3 immunoexpression in the cytoplasm of both hepatic and renal cells as indicated by dark brown color when compared with all other groups.
Considerable reduction in Caspase-3 immunostaining was noted in livers and kidneys of $0.2 \% \mathrm{PBO}$, or 0.2 $\%$ PBO plus SINPV. Microscopic observation of hepatic and renal tissues of rats treated with $0.1 \%$ PBO, or $0.1 \%$ PBO plus SINPV displayed weak reaction for caspase 3 in the liver and kidney (Fig 7 and table 8).

\section{ii. PCNA Immunoexpression}

Liver and kidney tissues stained for PCNA antibodies of both normal control group and SINPV treated groups showed limited immune reaction in hepatocytes, while PCNA-positive cells were not found in the kidney sections. In $0.3 \%$ PBO, and $0.3 \%$ PBO plus SINPV treated rats, both liver and kidney cells showed abundant nuclear PCNA-positive immunostaining with a significant increase in PCNA-LI, as proliferating cells in hepatic parenchyma, while in renal tissues PCNA-positive cells were demonstrated in interstitial tissue and within tubular cells. Examination of the $0.2 \%$ PBO, or $0.2 \%$ PBO plus SINPV treated groups revealed a significant decrease in PCNA-LI in both liver and kidney tissues when compared with $0.3 \%$ PBO, or $0.3 \%$ PBO plus SINPV treated rats, where kidney cells demonstrated a marked reduction of positive stained nuclei, but some hepatocytes were still positively stained. Examination of the liver and kidney sections of $0.1 \%$ PBO, or $0.1 \%$ PBO plus SINPV groups showed a limited PCNA-positive nuclear immune reaction when compared with other treated groups (Figure 8 and table 8).

\section{iii- TNF- $\alpha$ immunoexpression}

Regarding TNF- $\alpha$ immunoexpression, it was not surprising to observe the significant increase of TNF$\alpha$ cytoplasmic expression in hepatic and renal cells of rats that were treated with $0.3 \% \mathrm{PBO}$, or $0.3 \% \mathrm{PBO}$ plus SINPV when compared with other groups. However, such strong positive TNF- $\alpha$ immunoreactivity was declined in animals subjected to the treatment of $0.2 \% \mathrm{PBO}$, as well, in rats subjected to the dual treatment $0.2 \%$ PBO plus SINPV . The minimal immunoexpression of TNF- $\alpha$ was observed in each of $0.1 \% \mathrm{PBO}$, or $0.1 \% \mathrm{PBO}$ plus SINPV which revealed insignificant difference in TNF- $\alpha$ reactivity with both control and SINPV treated group neither in liver nor in kidney (Fig. 9 and table 8). 


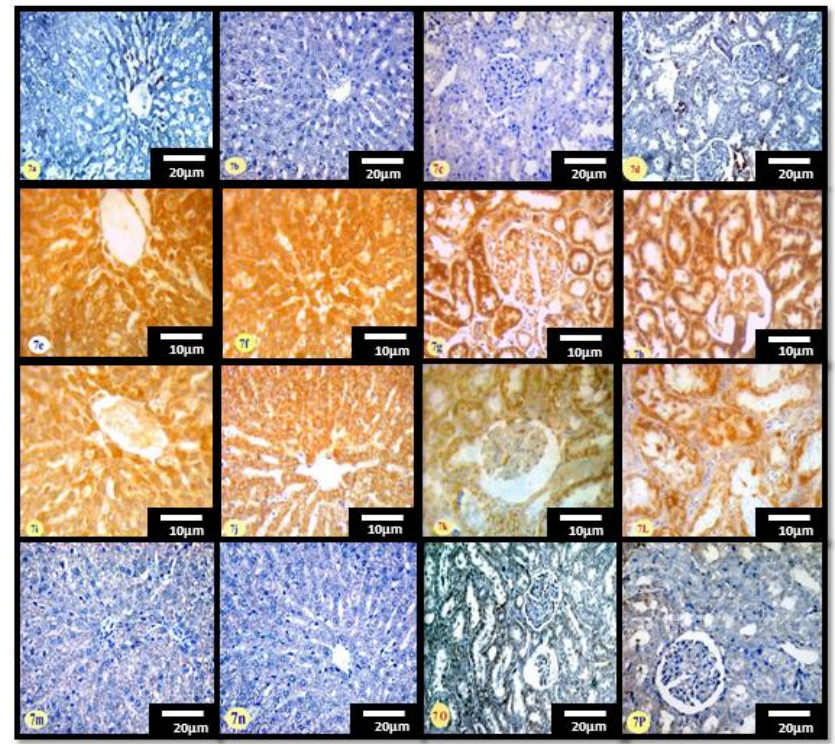

Fig. (7): The alterations of Caspase-3 immunoexpression in liver and kidney in experimental groups (Caspase-3 immunostain, X400). (7a) Liver section from a control rat showing negative Caspase-3 immunostained hepatocytes. (7b) Liver section of a SINPV treated rat showing weak Caspase-3 expression. (7c) Renal section of a control rat showing weak Caspase-3 immunostain. (7d) Renal section of a rat from SINPV group showing negative Caspase-3 expression. (7e) Liver section of $0.3 \%$ PBO treated rat showing strong Caspase-3 immunostain. (7f) Liver section of $0.3 \%$ PBO + SINPV treated rat showing strong Caspase-3 expression. (7g) Kidney section from rat treated with $0.3 \%$ PBO showing strong Caspase-3 immunostain. (7h) Kidney section of rat treated with $0.3 \%$ PBO + SINPV showing strong Caspase-3 immunoexpression. (7i) Liver section from $0.2 \%$ PBO treated rat showing moderate Caspase-3 expression. (7j) Liver section from $0.2 \%$ PBO + SINPV treated rat showing moderate Caspase-3 immunoexpression. (7k) Kidney section of $0.2 \%$ PBO treated rat showing moderate Caspase-3 stain. (7L) Kidney section of $0.2 \%$ PBO + SINPV treated rat showing moderate Caspase-3. (7m) Liver section from $0.1 \%$ PBO treated rat showing mild Caspase-3 stain. (7n) Liver section from 0.1\% PBO + SINPV showing weak Caspase-3 immunostain. (70) Kidney section of rat from $0.1 \%$ PBO treated group showing normal weak Caspase-3 immunoexpression. (7p) Kidney section of rat from 0.1\% PBO + SINPV treated group showing normal weak Caspase-3 immunoexpression.

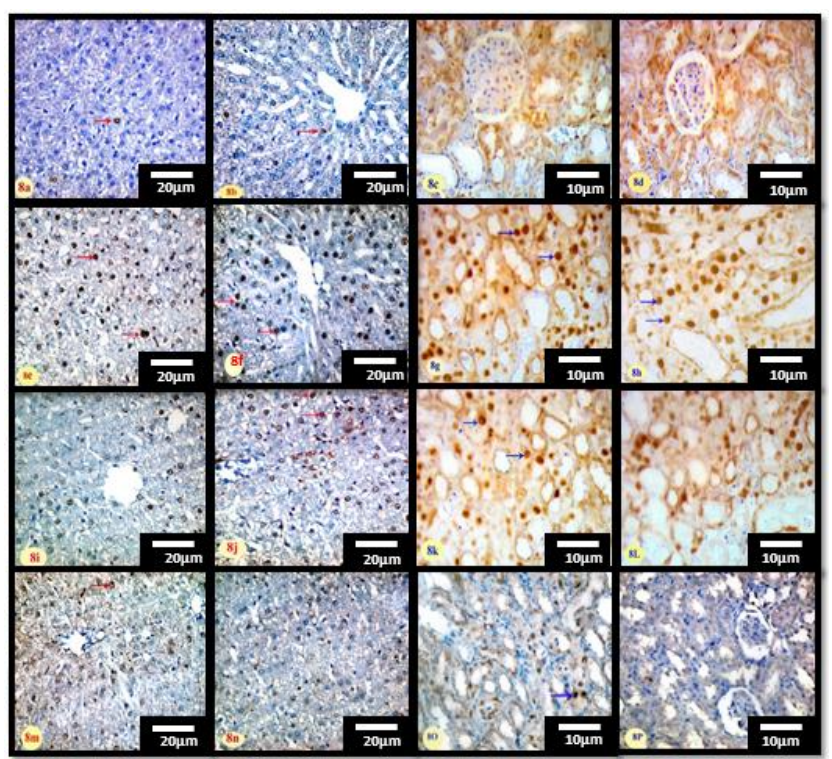

Fig. (8): The alterations of PCNA immunoexpression in nuclei of liver and kidney cells in experimental groups (PCNA immunostain, X400). (8a) Liver section from a control rat showing negative PCNA immunostained hepatocytes. (8b) Liver section of a SINPV treated rat showing weak PCNA expression. (8c) Renal section of a control rat showing weak PCNA immunostain. (8d) Renal section of a rat from SINPV group showing negative PCNA expression. (8e) Liver section of $0.3 \%$ PBO treated rat showing strong PCNA immunostain. (8f) Liver section of $0.3 \%$ PBO + SINPV treated rat showing strong PCNA expression. (8g) Kidney section from rat treated with $0.3 \%$ PBO showing strong PCNA immunostain. $(8 \mathrm{~h})$ Kidney section of rat treated with $0.3 \%$ PBO + SINPV showing strong PCNA immunoexpression. (8i) Liver section from $0.2 \%$ PBO treated rat showing moderate PCNA expression. (8j) Liver section from $0.2 \%$ PBO + SINPV treated rat showing moderate PCNA immunoexpression. (8k) Kidney section of $0.2 \%$ PBO treated rat showing moderate PCNA stain. (8L) Kidney section of $0.2 \%$ PBO + SINPV treated rat showing moderate PCNA. (8m) Liver section from 0.1\% PBO treated rat showing mild PCNA stain. (8n) Liver section from 0.1\% PBO + SINPV showing weak PCNA immunostain. (8O) Kidney section of rat from $0.1 \%$ PBO treated group showing normal weak PCNA immunoexpression. (8p) Kidney section of rat from $0.1 \%$ PBO + SINPV treated group showing normal weak PCNA immunoexpression. 


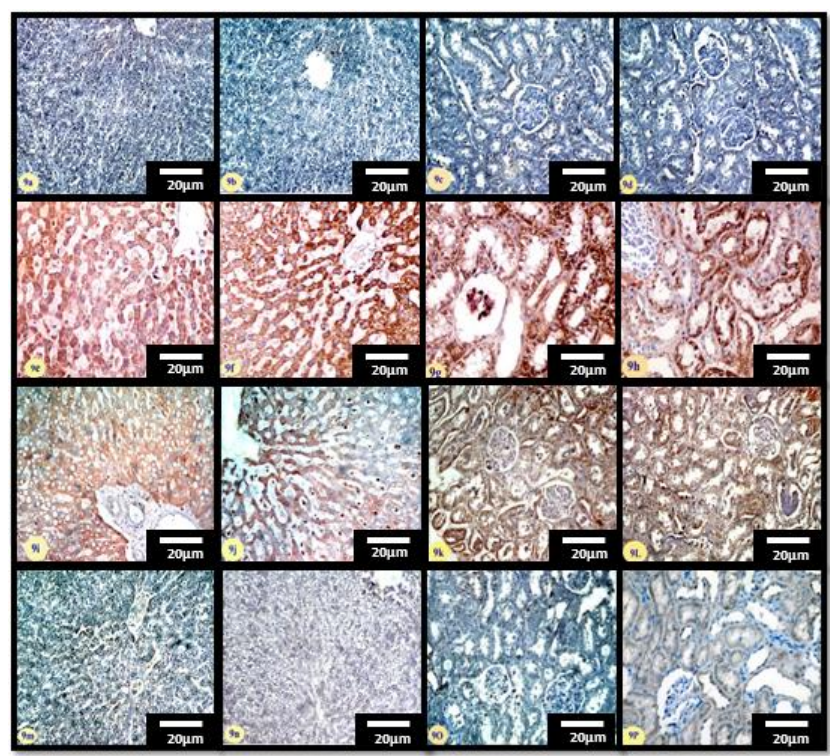

Fig-9: The changes of TNF- $\alpha$ immunoexpression in liver and kidney tissues in experimental groups (TNF- $\alpha$ immunostain, X400). (9a) Liver section from a control rat showing negative TNF- $\alpha$ immunostained hepatocytes. (9b) Liver section of a SINPV treated rat showing weak TNF- $\alpha$ expression. (9c) kidney section of a control rat showing weak TNF- $\alpha$ immunostain. (9d) kidney section of a rat from SINPV group showing negative TNF-a expression. (9e) Liver section of $0.3 \%$ PBO treated rat showing strong TNF- $\alpha$ immunostain. (9f) Liver section of $0.3 \%$ PBO + SINPV treated rat showing strong TNF- $\alpha$ expression. (9g) Kidney section from rat treated with $0.3 \%$ PBO showing strong TNF- $\alpha$ immunostain. (9h) Kidney section of rat treated with 0.3\% PBO + SINPV showing strong TNF-a immunoexpression. (9i) Liver section from $0.2 \%$ PBO treated rat showing moderate TNF- $\alpha$ expression. (9j) Liver section from 0.2\% PBO + SINPV treated rat showing moderate TNF-a immunoexpression. (9k) Kidney section of $0.2 \%$ PBO treated rat showing moderate TNF- $\alpha$ stain. (9L) Kidney section of $0.2 \%$ PBO + SINPV treated rat showing moderate TNF- $\alpha .(9 \mathrm{~m})$ Liver section from 0.1\% PBO treated rat showing mild Caspase-3 stain. (9n) Liver section from 0.1\% PBO + SINPV showing weak TNF- $\alpha$ immunostain. (90) Kidney section of rat from $0.1 \%$ PBO treated group showing normal weak TNF- $\alpha$ immunoexpression. (9p) Kidney section of rat from $0.1 \%$ PBO + SINPV treated group showing normal weak TNF-a immunoexpression

Biochemical analysis of serum MDA and TAC

As shown in table 9 Sera of both control and SINPV treated groups showed normal values of MDA and TAC with insignificant difference between control group and SlNPV group neither in MDA nor in TAC values. Treating animals with $0.3 \% \mathrm{PBO}$, or with $0.3 \% \mathrm{PBO}+$ SINPV induced a significant increase of MDA and a significant reduction of TAC when compared with other groups, however, no statistical differences were detected between $0.3 \% \mathrm{PBO}$, and $0.3 \% \mathrm{PBO}+S I N P V$ treated groups. Improvement of oxidative statues were achieved by reducing PBO treatment dose, as at rats group treated with $0.2 \%$ PBO alone or in combination SINPV resulted in reducing MDA and increase in TAC, and then ideal oxidative status was detected in animals treated with $0.1 \%$ PBO, or with $0.1 \% \mathrm{PBO}+S I \mathrm{NPV}$ as MDA and TAC values were nearly similar to those of control and SlNPV groups (table 9).

\section{In-vitro SRB cytotoxicity assay}

Data in table 10 showed OEC and Vero cell lines treated with different concentrations of PBO $(0.3 \%$, $0.2 \%, 0.1 \%$ ) compared with a control of untreated cells. Data recorded revealed that viability percentage and PBO dose concentration were related. OEC and Vero cells that were treated with $0.3 \%$ PBO revealed the highest cytotoxic activities and the lowest viability percentage, when compared with cells treated with $0.2 \% \mathrm{PBO}$, and $0.1 \% \mathrm{PBO}$, while $0.2 \%$ $\mathrm{PBO}$ treated OEC and Vero caused higher viability percentage. The highest cell viability percentage in both OEC and Vero cells was achieved in $0.1 \%$ PBO treatment that increased significantly when compared with both $0.2 \% \mathrm{PBO}$, and $0.3 \%$ PBO. 
Table-8: Morphometric evaluations of histological scoring and immunohistochemical changes in Caspase-3 \%, PCNA-Li, TNF- $\alpha \%$ within different groups (mean \pm SD, $n=7$ ).

\begin{tabular}{|c|c|c|c|c|c|c|c|c|}
\hline \multirow{2}{*}{ Parameter } & Histological scoring & \multicolumn{5}{|c|}{ Image analyses of Immunohistochemical changes } \\
\cline { 2 - 8 } & \multirow{2}{*}{ Liver } & \multirow{2}{*}{ Kidney } & \multicolumn{3}{|c|}{ liver } & \multicolumn{3}{|c|}{ kidney } \\
\cline { 4 - 9 } & & & Caspase- $3 \%$ & PCNA-Li & TNF- $\alpha \%$ & Caspase- $\% \%$ & PCNA-Li & TNF- $\alpha \%$ \\
\hline Control & $1.42 \pm 0.53$ & $1.57 \pm 0.53$ & $7.71 \pm 1.11$ & $15.14 \pm 0.69$ & $10.71 \pm 1.38$ & $7.28 \pm 0.95$ & $7.85 \pm 1.06$ & $7.85 \pm 1.21$ \\
\hline SINPV & $1.28 \pm 0.48^{\mathrm{a}}$ & $1.71 \pm 0.75^{\mathrm{a}}$ & $9.00 \pm 1.41^{\mathrm{a}}$ & $14.00 \pm 1.15^{\mathrm{a}}$ & $9.85 \pm 0.69^{\mathrm{a}}$ & $8.42 \pm 0.97^{\mathrm{a}}$ & $7.42 \pm 1.27^{\mathrm{a}}$ & $7.14 \pm 0.69^{\mathrm{a}}$ \\
\hline PBO 0.3\% & $7.57 \pm 0.53$ & $6.85 \pm 0.69$ & $51.71 \pm 4.75$ & $49.85 \pm 2.67$ & $53.85 \pm 1.95$ & $48.42 \pm 1.71$ & $32.14 \pm 3.02$ & $52.00 \pm 1.82$ \\
\hline PBO 0.3\% + SINPV & $7.42 \pm 0.53^{\mathrm{b}}$ & $6.71 \pm 0.75^{\mathrm{b}}$ & $54.71 \pm 5.02^{\mathrm{b}}$ & $47.85 \pm 4.14^{\mathrm{b}}$ & $54.85 \pm 2.03^{\mathrm{b}}$ & $50.14 \pm 2.60^{\mathrm{b}}$ & $31.71 \pm 2.13^{\mathrm{b}}$ & $50.57 \pm 1.51^{\mathrm{b}}$ \\
\hline PBO 0.2\% & $5.85 \pm 0.69$ & $5.14 \pm 0.37$ & $36.28 \pm 5.58$ & $34.71 \pm 2.92$ & $41.57 \pm 2.22$ & $33.42 \pm 4.11$ & $22.28 \pm 1.79$ & $38.28 \pm 1.79$ \\
\hline PBO 0.2\% + SINPV & $6.00 \pm 0.57^{\mathrm{b}}$ & $5.28 \pm 0.75^{\mathrm{b}}$ & $38.14 \pm 4.45^{\mathrm{b}}$ & $33.14 \pm 2.41^{\mathrm{b}}$ & $40.57 \pm 1.98^{\mathrm{b}}$ & $35.28 \pm 3.59^{\mathrm{b}}$ & $23.14 \pm 2.41^{\mathrm{b}}$ & $37.85 \pm 2.11^{\mathrm{b}}$ \\
\hline PBO 0.1\% & $1.57 \pm 0.78^{\mathrm{a}}$ & $1.85 \pm 0.69^{\mathrm{a}}$ & $9.57 \pm 1.13^{\mathrm{a}}$ & $14.28 \pm 2.49^{\mathrm{a}}$ & $12.28 \pm 1.49^{\mathrm{a}}$ & $8.85 \pm 1.06^{\mathrm{a}}$ & $9.42 \pm 0.97^{\mathrm{a}}$ & $9.42 \pm 1.27^{\mathrm{a}}$ \\
\hline PBO 0.1\% + SINPV & $1.71 \pm 0.48^{\mathrm{a}, \mathrm{b}}$ & $2.00 \pm 0.57^{\mathrm{a}} \mathrm{b}$ & $10.71 \pm 1.11^{\mathrm{a}, \mathrm{b}}$ & $15.28 \pm 1.88^{\mathrm{a}, \mathrm{b}}$ & $11.28 \pm 1.79^{\mathrm{a}, \mathrm{b}}$ & $10.00 \pm 1.52^{\mathrm{a}, \mathrm{b}}$ & $9.71 \pm 1.11^{\mathrm{a}, \mathrm{b}}$ & $8.57 \pm 1.51^{\mathrm{a}, \mathrm{b}}$ \\
\hline
\end{tabular}

(a), insignificant difference when compared with control group ; $(b)$ insignificant difference when compared with parallel $P B O$ only treated group $(p<0.01)$.

Table-9: Biochemical investigations of serum MDA and TAC changes in within different groups (mean \pm SD, n=7).

\begin{tabular}{|c|c|c|c|c|c|c|c|c|}
\hline \multirow{2}{*}{ Parameter } & \multicolumn{7}{|c|}{ Group } \\
\cline { 2 - 9 } & Control & S/NPV & PBO 0.3\% & $\begin{array}{c}\text { PBO 0.3\%+ } \\
\text { S/NPV }\end{array}$ & PBO 0.2\% & $\begin{array}{c}\text { PBO 0.2\% }+ \\
\text { S/NPV }\end{array}$ & $\begin{array}{c}\text { PBO 0.1\% } \\
\text { PBO 0.1\%+ } \\
\text { S/NPV }\end{array}$ \\
\hline MDA & $158.85 \pm 3.18$ & $160.85 \pm 4.18^{\mathrm{a}}$ & $291.00 \pm 4.28$ & $295.28 \pm 7.52^{\mathrm{b}}$ & $218.85 \pm 7.12$ & $227.14 \pm 6.64^{\mathrm{b}}$ & $163.00 \pm 3.31^{\mathrm{a}}$ & $166.28 \pm 2.49^{\mathrm{a}, \mathrm{b}}$ \\
\hline TAC & $27.28 \pm 2.21$ & $25.57 \pm 1.71^{\mathrm{a}}$ & $11.71 \pm 0.95$ & $10.28 \pm 0.48^{\mathrm{b}}$ & $19.14 \pm 1.95$ & $16.85 \pm 1.34^{\mathrm{b}}$ & $26.00 \pm 2.30^{\mathrm{a}}$ & $24.42 \pm 2.37^{\mathrm{a}, \mathrm{b}}$ \\
\hline
\end{tabular}

(a) Insignificant difference when compared with control group; $(b)$ insignificant difference when compared with parallel PBO only treated group $(p<0.01)$.

Table-10: Percentage viability of OEC and Vero cells after treatment with $P B O$ at different doses, and un treated cells. Each data point represents the mean \pm SD $(($ mean \pm SD, $n=5)$.

\begin{tabular}{|l|c|c|c|c|}
\hline \multirow{2}{*}{$\begin{array}{l}\text { Cell } \\
\text { lines. }\end{array}$} & \multicolumn{4}{|c|}{ Conc. } \\
\cline { 2 - 5 } & $\mathbf{0 . 3 \%}$ PBO & $\mathbf{0 . 2 \%}$ PBO & $\mathbf{0 . 1 \%}$ PBO & 0-PBO \\
\hline OEC & $41.80 \pm 3.03$ & $62.60 \pm 3.43$ & $85.40 \pm 4.61^{\mathrm{a}}$ & $100.00 \pm 0.00$ \\
\hline Vero & $37.20 \pm 4.76$ & $54.60 \pm 5.02$ & $78.00 \pm 5.87^{\mathrm{a}}$ & $100.00 \pm 0.00$ \\
\hline
\end{tabular}

Insignificant difference when compared with control untreated group, significant differences at $(p<0.01)$.

\section{Discussion}

Viral symptoms obtained in this study was in agreement with Tanada and Kaya (1993), in which the larval cuticle appear pale and milky color and this symptom can be associated with infection of the hypodermal cells. Symptom appeared in the intermediate stage of infection was swollen larval bodies which could be due to hypertrophy that had occurred in the cells and increasing of the nucleus (the main organ of virus reproduction) size as a result of viral infection. Liquefaction is the final and most characteristic symptom of viral infection in which the larval body appeared full of millions of VOBs causing complete damage and destruction of all larval tissues and organs, then release to the environment to spread the infection and infect other hosts (El Salamouny, 2007). The viral infection begins when the larvae ingested food contaminated with occlusion bodies (OBs), which reached the larval midgut and dissolved by the alkaline digestive juice of the midgut lumen, (Moore and Manousis, 1986). SINPV virions release and spread within the midgut to cause larval infection (Petrik et al., 2003). Our SlNPV toxicity results confirm those of Abd ElAziz (1999) and Mahmoud et al. (2009) who proved that the $2^{\text {nd }}$ instar larvae of $S$. littoralis was highly susceptible to NPV than the $4^{\text {th }}$ instar larvae. Sensitivity of the $S$. littoralis younger instar to NPV was reported by several authors (Pawar and Ramakrishnan, 1975; Klein and Podoler, 1978; Seufi and Osman, 2005 and Seufi, 2008).

Stairs (1965) found that the susceptibility to NPV decreased as larvae of Malacosoma disstria grew older. In parallel Duan and Otvos (2001) reported that mortality was higher as younger instar larvae of 
Choristonura fumiferana were used, Wilson et al. (2000) also mentioned that $2^{\text {nd }}$ instar larvae were more susceptible to AcMNPV than $4^{\text {th }}$ instar larvae of cabbage looper, Trichoplusia ni. Also, Cherry et al. (2000) proved that the susceptibility of Helicoverpha armigera to HearNPV depends on the larval age, and Bourner et al. (1992) emphasized that earlier instar has speed of kill by AsNPV than older instar larvae of Agrotis segetum

Our results showed that high NPVs concentrations caused high mortality rate and this conclusion is in line with Sutanto et al. (2014) who studied the infectivity of SlNPV against $1^{\text {st }}$ and $2^{\text {nd }}$ instar larvae of $S$. littoralis and found that mortality percentage of the larvae was greater at the highest concentration of the virus than at lowest concentrations.

Baculovirus is potential microbial insecticide play a major role in the suppression of a variety of different types of insects. There are several reviews in using baculovirus for controlling different insect family (Szewczyk et al., 2006). The most serious disadvantage of using baculovirus as effective insecticide is slow speed of kill which give chance for the pests to infest the crops and cause complete damage to them. The long time required by baculovirus to kill insects is due to insect metabolic resistance which is considered common defense mechanism based on the enzymatic system that protect insects.

Synergists are chemical compounds which significantly improve the efficacy of insecticides by increasing lethality and effectiveness of them. Using of the synergists in addition to insecticides is considered the best way to overcome resistance to insecticides by damaging binding site of the detoxification enzymes and make the insecticides more toxic to pests (Corbel et al., 2010 and Pennetier et al., 2013). The most common and effective insecticide synergist used is PBO.

Our results proved that when $S$. littoralis larvae were pre-treated with PBO before being treated with the viral isolate, there was significant enhancement of the larval susceptibility to the virus and increasing in the larval death in a short time. These results are in agreement with Cakir et al. (2008) who investigated the effect of $\mathrm{PBO}$ on the biological activity of three insecticides and showed that PBO extensively promoted their efficacy against different housefly population. In parallel,

Dáder et al. (2019) examined a wide range of insecticides with different modes of action against
Philaenus spumarius and indicated that, some of these insecticides are not effective when applied alone and their efficacy was enhanced by using PBO which caused a 3-fold increase in the mortality of $P$. spumarius nymphs. Dadzie et al. (2017) investigated the effect of PBO on the susceptibility of Anopheles gambiae mosquitoes treated with pyrethroid insecticides and found that when the mosquitoes were pre-exposed to $\mathrm{PBO}$ before exposure to deltamethrin or permethrin, there was a significant enhancement of their susceptibility to these insecticides. Ahmed and Vogel (2016) evaluated the synergistic effects of PBO on the toxic activity of 16 insecticides against Aedes aegypti adults and confirmed the strongly synergistic effect of PBO with all insecticides types used.

AchE is key enzyme in detoxification of neurotoxic insecticides (their target is nervous system) and overproduction of AchE catalyzes the breakdown of acetylcholine and some other choline esters which acts as neurotransmitters (Byrne and Toscano, 2001). Nonspecific esterase ( $\alpha$ - esterase and $\beta$ - esterase) is another important enzyme, detoxify several pesticides by two main ways, hydrolysis of the ester bond and binding of the pesticide to the active site of esterase (Crow et al., 2007). GST plays critical role in detoxification of insecticides by conjugating reduced glutathione to the electrophilic centers of insecticides. (Enayati et al., 2005). Multi-function oxidases is one of the most important enzyme of insect resistance mechanism (Qi et al., 2016), it introduces one or more polar groups into the substrate in Phase I metabolism and make them suitable for conjugation at Phase II reaction of detoxification (Kranthi, 2005). LDH is an important glycolytic enzyme that is present approximately in all tissues (Kaplan and Pesce, 1996). It is involved in carbohydrate metabolism and has been used as an indicator for exposure to chemical stress (Diamantino et al., 2001). LDH is also a parameter used widely in toxicology and clinical chemistry to diagnose cell, tissue, and organ damage. GOT and GPT are also named aspartic transeferase (AST) and (ALT). They are key enzymes in the formation of amino acids, gluconeogenesis, metabolism of the nitrogen compound, and associated with protein synthesis (Mordue and Goldworthy, 1973). All these enzymes are involved in insect's defense process due to their genetic diversity, broad substrate specificity and catalytic versatility.

It is clear from the results that the concentration of 
PBO used in this study enhance the effectiveness of viral isolate by making disturbance of the tested insect enzyme either with increase or decrease, and this indicates that toxic effect of PBO affects the synthesis or function of these enzymes by altering cytomorphology of the cells (Nath, 2000). Our findings are in line with Todeschini et al. (2017) who measure enzymes activities in Italian and Carniolan honey bees treated with PBO and some of its derivatives and found that only esterase enzyme activity was inhibited while other enzymes like MFO, GST and AchE were not affected and seem not to be targeted by the tested synergists. Pereira et al. (2014) studied the effect of PBO on the toxicity of organophosphate temephos against Aedes aegypti and showed that PBO cause inhibition of the total esterase activity while some concentration caused activation of MFO enzyme. Matowo et al. (2010) investigated the combined effect of permethrin and PBO on Anopheles arabiensis and their action on enzymes activity and noticed inhibition of the activity of both MFO and B-esterase and concluded that PBO increase the efficacy of permethrin. In the same line Joffe et al. (2011) determined the efficacy of seven natural compounds compared with PBO in synergising pyrethrum in houseflies and proved that PBO was the most effective synergist and this was associated with inhibition of esterase and oxidase enzyme activity.

Enhancement and inhibition in the enzyme activity are indication of dysfunction and alternation of the metabolic enzyme system. Increase the activity of some enzyme like GPT is related to increase of lipid peroxidase which mean generation of free radical in cell membrane resulting in cell damage (Icen et al., 2005). GOT and GPT enzyme are biomarker for determination of tissue injury of vertebrates (Patil et al., 2003), increase of the activity of them or one of them mean impairment in amino acid metabolism. Increasing and decreasing of enzyme activity recorded in our study may be due to depression or mutations of the regulating genes responsible for biosynthesis of polypeptide chains constructing this enzyme (Hassanien et al., 1996).

The presented histopathological results showed that no statistical differences were recorded between $0.3 \% \mathrm{PBO}+S l \mathrm{NPV}, 0.2 \% \mathrm{PBO}+S l \mathrm{NPV}$ or $0.1 \%$ PBO + SINPV, with $0.3 \%$ PBO, $0.2 \%$ PBO or $0.1 \%$ PBO treated groups respectively within all histological, morphometric, immunohistochemical, biochemical and cytological studies. These findings suggested that SlNPV with our suggested dose is safe and has not any pathological effects on rat tissues and cells. In addition, the ineffective impact of PBO on the nature and activity of SlNPV. The safety of SlNPV on experimental animals was previously discussed in several studies. Döller et al. (1983) reported that NPV didn't induce any pathological alterations in neither lymph nodes nor 125I-labeled polyhedrin binding capacity in NPV-fed pigs when compared with control animals. Ashour et al. (2007) studied the histopathological effects of SINPV on stomach, intestine, liver, kidney, brain, spleen and lung tissues in SlNPV-orally treated male and female rats. The findings reported by-Ashour et al. (2007) revealed that no histopathological changes induced by $S l N P V$ oral or intraperitoneally injection. Moreover, no mortality over a 21 day-long observation period, no indications of toxicity were observed by hematological and clinical biochemical analyses. Infectivity of $\mathrm{HaNPV}$ in intravenous infected rats has been reported by Zhao et al. (2019) who found that no obvious toxic symptoms or mortality were observed during the experimental period. HaNPV didn't induce any amplification bands by PCR test, histopathological changes or specific lesion in brain, blood, lymph nodes, liver, spleen, lung, kidney, and cecum contents by PCR test.-(Zhao et al., 2019).

Current histological and cytotoxicity results showed the pathogenicity of $0.3 \%$ and $0.2 \%$ PBO as there were moderate degrees of liver and kidney tissues damages, which were clarified by immunohistochemical observations as apoptosis and inflammation through the significant increase of immunoreactivity of Caspase-3, PCNA-Li and TNF$\alpha$ respectively, then with serum biochemical analyses as oxidative stress. Pathological effects of increased doses of PBO on animals were reported by several authors. Fukuyama et al. (2013) suggested that PBO cause T-lymphocyte apoptosis via initiation of Caspase-3 activities in different cells. Phillips et al. (1997) reported that histological examinations of liver tissues of PBO - treated rats showed necrosis in hepatocytes. In addition, they observed that the necrosis severity was dose-dependent. PBO can damage DNA via oxidative stress in rats (Muguruma et al., 2007 and Arslan et al., 2016). Therefore, the histopathological impacts of PBO in our study could be related to oxidative stress induced by $\mathrm{PBO}$. Oxidative stress contributes to the increase in caspase-3 immunoreactivity, and proteolytic 
activation and subsequent DNA fragmentation, which eventually results in apoptotic cell death (Kim et al., 2000). Role of oxidative stress in disturbances of TNF- $\alpha$, one of the most important inflammatory cytokines, has been evidenced. TNF- $\alpha$ is increased in the early stage of inflammation and initiate the ROS production (Zhu et al., 2020).

Ibrahim et al. (2019) found that, the increased ROS and proinflammatory cytokines induce renal dysfunction and damage the increased TNF- $\alpha$ is associated with the increase of oxidative stress. TNFalpha activates different intracellular pathways to control inflammation, proliferation and apoptosis in both liver and kidney (Schwabe and Brenner, 2006 and Vielhauer and Mayadas, 2007). Regarding PCNA overexpression in liver and kidney tissues, it has been reported that PCNA formation takes place after oxidative stress in order to repair and attenuate the oxidative DNA damage (Balajee et al., 1999 and Tsai et al., 2017). Dose concentration - dependent decreased histopathological changes were observed by comparing $0.3 \%$ and $0.2 \%$ PBO treated rats, which may also explain the significant depletion in pathogenicity of $0.1 \%$ PBO treated rats, where the liver and kidney tissues seems to normal control tissues.

\section{Conclusion}

In this study, the ultimate goal was to overcome on the viral slow speed of action which limits its application despite its great effectiveness in plant pests control and use as a safe and environmentally friendly biocontrol agent by using $\mathrm{PBO}$ as a synergistic agent with SINPV. The results showed that $0.1 \%$ of $\mathrm{PBO}$ had a high degree of tissue biosafety and proved its synergistic effect, so that, it could be used as a synergistic agent with SINPV for enhancing the viral activity to be used as a potential biocontrol agent

Abbreviation table
\begin{tabular}{|l|l|}
\hline AchE & Actylcholin esterase \\
\hline ALT & Alanine transaminase \\
\hline AST & Aspartic transeferase \\
\hline CDNB & 1-chloro2,4-dinitrobenzene \\
\hline GOT & Glutamic oxaloacetic transaminase \\
\hline GPT & Glutamic pyruvic transaminase \\
\hline GST & Glutathione S-transferase \\
\hline LC $_{50}$ & Lethal concentration that kill $50 \%$ of \\
\hline
\end{tabular}

\begin{tabular}{|l|l|}
\hline & pest \\
\hline LDH & Lactate dehydrogenase \\
\hline MDA & Malondialdehyde \\
\hline MFO & Multi-function oxidases \\
\hline NRC & National Research Center \\
\hline PBO & Pipronyl butoxide \\
\hline PCNA & Proliferating cell nuclear antigen \\
\hline POB/ml & Polyhedral occlusion bodies per milliliter \\
\hline SlNPV & Spodoptera littoralis nucleopolyhedrosis \\
\hline SRB & Cell culture Sulforhodamine B \\
\hline TAC & Total antioxidant capacity \\
\hline TAC & Total anti-oxidant capacity \\
\hline TNF- $\alpha$ & Tumor necrosis factor - alpha \\
\hline VOBs & Viral occlusion bodies \\
\hline
\end{tabular}

\section{Ethics Approval and Consent to Participate}

The protocol and consent form were approved by Suez University Research Ethics Committee.

All participants provided written informed consent.

Disclaimer: None.

Conflict of Interest: None.

Source of Funding: None.

\section{References}

Abd El-Aziz NM, 1999. Pathological studies on Egyptian cotton leafworm, Spodoptera littoralis, infected with entomopathogenic viruses. Faculty of Science, Cairo University, Egypt, 67-79.

Abdel-Dayem MM, 2009. Histological and Immunohistochemical Changes in the Adult Rat Testes after Left Experimental Varicocele and Possible Protective Effects of Resveratrol. Egypt. J. Histol. 32(1): 81-90.

Addy ND, 1969. Rearing the forest tent caterpillar on an artificial diet. J. Econ. Entomol. 62: 270-271.

Ahmed MAI and Vogel CFA, 2016. Effects of Piperonyl Butoxide on the Toxicity of Novel Selected Insecticides against Aedes aegypti L. (Diptera: Culicidae) Adults Australian. J. Basic Appl. Sci. 10(12):248-254

Ahmed YE, Desoky Sh M, El-Sabagh MM and Sofy AR, 2016. Molecular and biological characterization of a nucleopolyhedrovirus Isolate (Egy-SlNPV) from Spodoptera littoralis in Egypt. Int. J. Virol. Mol. Biol. 5:34-45

Alves SB and Moraes SA, 1998. Quantificac, ão de inóculo de patógenos de insetos. In: Alves, S.B. (Ed.), Controle Microbiano de Insetos. FEALQ, 
Piracicaba, SP. 765-777.

Arslan M, Sevgiler Y, Buyukleyla M, Yardimci M, Yilmaz M and Rencuzogullari E, 2016. Sexrelated effects of imidacloprid modulated by piperonyl butoxide and menadione in rats. Part II: genotoxic and cytotoxic potential. Drug Chem. Toxicol. 39(1): 81-86.

Ashour MB, Ragheb DA, El-Sheikh EA, Gomaa EA, Kamita SG and Hammock BD, 2007. Biosafety of Recombinant and Wild Type Nucleopolyhedroviruses as Bioinsecticides. Int. J. Environ. Res. Public Health. 4(2), 111-125.

Aydin MH and Gürkan MO, 2006. The efficacy of spinosad on different strains of Spodoptera littoralis (Boisduval) (Lepidoptera: Noctuidae). Turk. J. Biol. 30:5-9.

Bakr EM, 2000. Ldp line 3. (Site of internet), http://www.Ehab soft.com.

Balajee AS, Dianova I and Bohr VA, 1999. Oxidative damage-induced PCNA complex formation is efficient in xeroderma pigmentosum group A but reduced in Cockayne syndrome group B cells. Nucl. Acids Res. 27(22): 44764482.

Bingham G, Strode C, Tran L, Khoa PT and Jamet P, 2011. Can piperonyl butoxide enhance the efficacy of pyrethroids against pyrethroid resistant Aedes aegypti?. Trop. Med. Int. Health. 16: 492-500.

Bourner TC, Vargas-Osuna E, Williams T, SantiagoAlvarez C and Cory JS, 1992. A comparation of the efficacy of nuclear polyhedrosis and granulosis viruses in spray and bait formulations for the control of Agrotis segetum (Lepidoptera: Noctuidae) in Maize. Biol. Sci. Technol. 2:315326

Breathnach R, 1998. The safety of piperonylbutoxide. In Piperonyl butoxide: The insecticide synergist (Jones DG., Ed.).p.7. Academic Press, San Diego, USA.

Byrne FJ and Toscano NC, 2001. An insensitive acetylcholinesterase confers resistance to methomyl in the beet armyworm Spodoptera exigua (Lepidoptera: Noctuidae) J. Econ. Entomol. 94:524-528.

Cakir G, Yavuz O and Kocak O, 2008. Effects of piperonyl butoxide and tetramethrin combinations on biological activities of selected synthetic pyrethroid insecticides against different housefly (Musca domestica L., Diptera: Muscidae) populations. Acta Vet. Brno. 77:467-
474.

Cheng XW and Lynn DE, 2009. Baculovirus interactions in vitro and in vivo. Adv. Appl. Microbiol. 68:217-239.

Cherry AJ, Rabindra RJ, Parnell MA, Geetha N, Kennedy JS and Grzywacz D, 2000. Field evaluation of Helicoverpa armigera nucleopolyhedrovirus formulations for control of the chickpea podborer, $H$. armigera (Hubn.), on chickpea (Cicer arietinum var. Shoba) in southern India. Crop Prot. 19:51-60.

Corbel V, Chabi J, Dabire RK, Etang J, Nwane P and Pigeon O, 2010. Field efficacy of a new mosaic long-lasting mosquito net (PermaNet 3.0) against pyrethroid-resistant malaria vectors: a multi centre study in Western and Central Africa. Malar J. 9:113.

Crow JA, Potter PM, Borazjani A and Ross MK, 2007. Title: Hydrolysis of pyrethroids by human and rate tissues: examination of intestinal, liver and serum carboxylestersaes. Toxicol. App. Pharmacol. 221:1-12

Dáder B, Aguirre E, Caballero $\mathrm{P}$ and Medina $\mathrm{P}$, 2020. Synergy of Lepidopteran Nucleopolyhedroviruses AcMNPV and SpliNPV with Insecticides. Insects. 11:316.

Dáder B, Viñuela E, Moreno A, Plaza M, Garzo E, Estal PD and Fereres, 2019. Sulfoxaflor and Natural Pyrethrin with Piperonyl Butoxide Are Effective Alternatives to Neonicotinoids against Juveniles of Philaenus spumarius, the European Vector of Xylella fastidiosa. Insects. 10(8):225

Dadzie SK, Chabi J, Asafu-Adjaye A, Owusu-Akrofi O, Baffoe-Wilmot A, Malm K, Bart-Plange C, Coleman S, Appawu MA and Boakye DA, 2017. Evaluation of piperonyl butoxide in enhancing the efficacy of pyrethroid insecticides against resistant Anopheles gambiae s.l. in Ghana. Malaria J. 16:342

Deutsche Gesellschaft für klinische Chemie. Empfehlungen der deutschen Gesellschaft für Klinische Chemie (DGKC), 1972. Standardisierung von Methoden zur Bestimmung von Enzymaktivitäten in biologischen Flüssigkeiten. (Recommendation of the German Society of Clinical Chemistry. Standardization of methods for measurement of enzymatic activities in biological fluids.) $\mathrm{Z}$ Klin. Chem. Klin. Biochem.10:182-92

Diab HST, 2011. The Status of pyrethroid resistance in field collected strains of the Spodoptera 
littoralis and role of piperonyl butoxide. J. Plant Prot. Pathol. Mansoura Univ 2:1005-1014.

Diamantino TC, Amadeu E, Soaresa MVM and Guilherminoc L, 2001. Lactate dehydrogenase activity as an effect criterion in toxicity tests with Daphnia magna Straus. Chemosphere. 45: 553560.

Döller G, Gröner A and Straub OC, 1983. Safety evaluation of nuclear polyhedrosis virus replication in pigs. Appl. Environ. Microbiol. 45(4):1229-1233.

Drury RA and Wallington EA, 1980. Carleton's Histological Techniques (1980) $5^{\text {th }}$ ed. Oxford: Oxford University Press. p. 362.

Duan L and Otvos IS, 2001. Influence of larval age and virus concentration on mortality and sublethal effects of a nucleopolyhedrovirus on the Western Spruce Bud worm (Lepidoptera: Tortricidae). J. Environ. Entomol., 30:136-146.

El-Defrawi ME, Toppozada A, Mansour N and Zeid M, 1964. Toxicological studies on the Egyptian cotton leaf worm Prodenia litura. I. Susceptibility of different larval instars of Prodenia to insecticides. J. Econ. Entomol. 57:591- 593

Eldridge SR and Goldsworthy SM, 1996. Cell proliferation rates in common cancer target tissues of B6C3F1 mice and F344 rats: effects of age, gender, and choice of marker. Fundamental Appl. Toxicol. 32: 159-167.

Elmenofy W, Salem R, Osman E, Yasser N, Abdelmawgod A, Saleh M, Zaki A, Hanafy E, Tamim S, Amin S, El-Bakry A, El-Sayed A and El-Gaied L, 2020 . Evaluation of two viral isolates as a potential biocontrol agent against the Egyptian cotton leafworm, Spodoptera littoralis (Boisd.) (Lepidoptera: Noctuidae). Egypt. J. Biolog. Pest Control. 30:75.

El-Salamouny SA, Lange M, Jutzi M, Huber J and Jehle JA, 2003. Comparative study on the susceptibility of cutworms (Lepidoptera: Noctuidae) to Agrotis segetum nucleopolyhedrovirus and Agrotis ipsilon nucleopolyhedrovirus. J. Invertebr. Pathol. 84:75-82.

El Salamouny SA, 2007. Observations on the peritrophic membrane of tortricid and noctuid insect and its role in susceptibility and enhancement. J. Agric. Urban. Entomol. 24(4):195-204.

Enayati AA, Ranson H and Hemingway J, 2005.
Insect glutathione transferases and insecticide resistance. Insect Mol. Biol. 14(1):3-8.

Finney DJ, 1971. Probit analysis: a statistical treatment of the sigmoid response carve. Cambridge: Cambridge University Press. p 318.

Fukuyama T, Kosaka T, Hayashi K, Miyashita L, Tajima $\mathrm{Y}$, Wada $\mathrm{K}$, Nishino $\mathrm{R}$, Ueda $\mathrm{H}$ and Harada T, 2013. Immunotoxicity in mice induced by short-term exposure to methoxychlor, parathion, or piperonyl butoxide. J. Immunotoxicol. 10(2):150-159.

Gunning RV, Moores GD and Devonshire AL, 1999. Esterase inhibitors synergise the toxicity of pyrethroids in Australian Helicoverpa armigera (Hubner) (Lepidoptera: Noctuidae). Pesticide Biochem. Physiol. 63:50-62.

Habig WH, Pabst MJ and Jakoby WB, 1974. Glutathione S-transferase. The first enzymatic step in mercapturic acid formation. J. Biol. Chem. 249:7130-7139.

Hansen LG and Hodgson E, 1971. Biochemical characteristics of insect microsomes. $\mathrm{N}$-and odemethylation. Biochem. Pharmacol. 20:15691578

Hassanien AHM, Baker RFA, Saleh NA and ElBermawy SM, 1996. Biochemical aberrations induced by three insect growth regulators in the house fly Musca domestica L. (Diptera: Muscidae). Ain Shams Sci. Bull. 34: 319-350.

Huang Q, Deng Y, Zhan T and He Y, 2010. Synergistic and antagonistic effects of piperonyl butoxide in fipronil-susceptible and resistant rice stem borrers, Chilo suppressalis. J. Insect. 10:182 Ibrahim A, Al-Hizab FA and Abushouk AI, 2019. Nephroprotective effects of benzyl 1sothiocyanate and resveratrol against cisplatininduced oxidative stress and inflammation. Front. Pharmacol. 9:1268.

Ibrahim MY, $\mathrm{Hj}$ Abdul AB, Ibrahim TT, Abdelwahab SI, Elhassan MM and Syam MM, 2010. Evaluation of acute toxicity and the effect of single injected doses of zerumbone on the kidney and liver functions in Sprague Dawley rats. Afr. J. Biotechnol. 9(28): 4442-4450.

Icen E, Armutcu F, Buyukguzel K and Gurel A, 2005. Biochemical Stress Indicators of Greater Wax Moth Exposure to Organophosphorus Insecticides J. Econ. Entomol. 98(2): 358-366

Jackson P, Blythe D, Bancroft JD and Gample M, 2008. Immunohistochemical techniques in theory and practice of histological technique $\left(6^{\text {th }}\right.$ ed.), 
Elsevier, China. P. 423.

Joffe T, Gunning RV, Allen GR, Kristensen M, Alptekin S, Field LM and Moores GD, 2011. Investigating the potential of selected natural compounds to increase the potency of pyrethrum against houseflies Musca domestica (Diptera:Muscidae) Pest Manage. Sci. 68: 178184

Kaplan LA and Pesce AJ, 1996. Clinical Chemistrytheory Analysis and Correlation. Mosby-Year Book, MO, 609-610.

Keane P, 1998. The use of piperonyl butoxide in formulations for the control of pests of humans, domestic pets and food animals, pp. 290-300. In: Piperonyl butoxide: The insecticide synergist (JONES D. G., Ed.). Academic Press, San Diego, USA.

Kim GW, Sugawara T and Chan PH, 2000. Involvement of oxidative stress and caspase- 3 in cortical infarction after photothrombotic ischemia in mice. J. Cerebral Blood Flow Metab. 20(12):1690-1701.

Klein M and Podoler H, 1978. Studies on an application of a Nuclearpolyhedrosis virus to control population of the Egyptian cotton worm S. littoralis. J. Invert. Pathol. 32:244-248.

Kranthi KR, 2005. Insecticide resistance monitoring mechanisms and management manual, Central Institute for Cotton Research, Shankar Nagar, Nagpur, India. p.88.

Lacey LA , Grzywacz D , Shapiro-Ilan DI , Frutos R , Brownbridge M and Goettel MS , 2015. Insect pathogens as biological control agents: Back to the future. J. Invertebr. Pathol.132:1-41.

Li SY and Skinner AC, 2005. Influence of Larval Stage and Virus Inoculum on Virus Yield in Insect Host Neodiprion abietis (Hymenoptera: Diprionidae). J. Econ. Entomol. 98:1876-1879

Mahmoud DM, Hamed R KA, Seufi AEM, Salama MS, Diwan NML and El Shafei AM, 2009. Toxicity and biological effects of three Egyptian isolates of baculovirus on the cotton leaf worm, Spodoptera littoralis (boisd). Egypt Acad. J. Biol. Sci. 2:219-226

Manfo FPT, Mboe SA, Nantia EA, Ngoula F, Telefo PB, Moundipa PF and Cho-Ngwa F, 2020. Evaluation of the Effects of Agro Pesticides Use on Liver and Kidney Function in Farmers from Buea, Cameroon. J. Toxicol. 2020: 2305764.

Matowo J, Kulkarni MA, Mosha FW, Oxborough RM, Kitau JA, Tenu F and Rowland M, 2010.
Biochemical basis of permethrin resistance in Anopheles arabiensis from Lower Moshi, northeastern Tanzania. Malar J. 79:193.

Mohamed HA, Alkordy MW and Atta AA, 2019. Effect of host plants on biology of Spodoptera littoralis (Boisd.). Egypt. Acad. J. Biol. Sci. 12:65-73.

Moore NF and Manousis T, 1986. The Use of Viruses for Controlling Pest Species of Insects. Entomologia Hellenica. 4:3-10

Moores GD, Philippou D, Borzatta V, Trincia P, Jewess P, Gunning R and Bingham G, 2009. An analogue of piperonyl-butoxide facilitates the characterisation of metabolic resistance. Pest Manage. Sci. 65:150-154.

Mordue W and Goldworthy GJ, 1973. Transaminase levels and uric acid production in adult locusts. Insect Biochem. 3:419-427.

Muguruma M, Unami A and Kanki M, 2007. Possible involvement of oxidative stress in piperonyl butoxide induced hepatocarcinogenesis in rats. Toxicol. 236:61-75.

Mustafa U, Adnan S, Gonul A, Hatice $\mathrm{O}$ and Suleyman A, 2001. Environmental pollution with soil transmitted helminths in Sanliurfa, Turkey. Oswaldo Cruz, Rio deJaneiro. 96(7):903-909.

Nath SB, 2000. Changes in carbohydrate metabolism in hemolymph and fat body of the silkworm, Bombyx mori L., exposed to organophosphorus insecticides. Pesticide Biochem. Physiol. 68(3):127-137.

Ohkawa H, Ohishi N and Yagi K, 1979. Assay of lipid peroxides in animal tissues by thiobarbituric acid reaction. Annals Biochem. 95:351-358.

Okail HA, Ibrahim AS and Badr AH, 2020. The protective effect of propolis against aluminum chloride-induced hepatorenal toxicity in albino rats. JoBAZ. 81:34.

Orfila C, Lepert JC, Gossart S, Frisach MF, Cambon C and Pipy B, 1998. Immunocytochemical characterization of lung macrophage surface pheno types and expression of cytokines in acute experimental silicosis in mice. Histochem J. 30:857-867.

Patil JA, Patil AJ and Govindwar SP, 2003. Biochemical effects of various pesticides on sprayers of grape gardens. Indian J. Clin. Biochem. 18:16-22.

Pawar VM and Ramakrishnan N, 1975. Investigation of the nucleopolyhedrovirus of Spodoptera litura. III- Bioassay of virus activity. Indian J. 
Entomol. 37: 374-376.

Pennetier C, Bouraima A, Chandre F, Piameu M, Etang $\mathrm{J}$ and Rossignol M, 2013. Efficacy of Olyset (R) Plus, a new long-lasting insecticidal net incorporating permethrin and piperonylbutoxide against multi-resistant malaria vectors. PLoS ONE. 8:e75134.

Pereira BB, Limongi JE, Júnior EOdC, Luiz DP and Kerr WE, 2014. Effects of piperonyl butoxide on the toxicity of the organophosphate temephos and the role of esterases in the insecticide resistance of Aedes aegypti. Revista da Sociedade Brasileira de Medicina Tropical 47(5):579-582.

Petrik DT, Iseli A, Montelone BA, VanEtten JL and Clem RJ, 2003. Improving baculovirus resistance to UV inactivation: Increased virulence resulting from expression of a DNA repair enzyme. J. Invertebr. Pathol. 82 (1):50-56.

Phillips JC, Price RJ, Cunninghame ME, Osimitz TG, Cockburn A, Gabriel KL, Preiss FJ, Butler WH and Lake BG, 1997. Effect of piperonyl butoxide on cell replication and xenobiotic metabolism in the livers of CD-1 mice and F344 rats. Fundamental Appl. Toxicol. 38(1):64-74.

Qi W, Ma X, He W, Chen W, Zou M and Gurr GM, 2016. Characterization and expression profiling of ATP-binding cassette transporter genes in the diamondback moth, Plutella xylostella, (L.). BMC Genomics. 17:760.

Radova S, 2010. Can pre-colonisation of the soil substrate increase the efficacy of entomopathogenic nematodes (Rhabditida: Steinernematidae). J. Agrobiol. 27(1):19-25.

Rapa SF, Di Iorio BR, Campiglia P, Heidland A and Marzocco S, 2019. Inflammation and Oxidative Stress in Chronic Kidney Disease-Potential Therapeutic Role of Minerals, Vitamins and Plant-Derived Metabolites. Int. J. Mol. Sci. 21(1):263.

Reitman S and Frankel S, 1957. Colorimetric method for aspartate and alanine transaminases. Am. J. Clin. Pathol. 28:56-63.

Roghani M, Kalantari H, Khodayar MJ, Khorsandi L, Kalantar M, Goudarzi M and Kalantar H, 2020. Alleviation of Liver Dysfunction, Oxidative Stress and Inflammation Underlies the Protective Effect of Ferulic Acid in Methotrexate-Induced Hepatotoxicity. Drug Des. Devel. Ther. 14:19331941

Schwabe RF and Brenner DA, 2006. Mechanisms of
Liver Injury. I. TNF-alpha-induced liver injury: role of IKK, JNK, and ROS pathways. Am. J. Physiol. Gastrointest. Liver Physiol. 290(4): G583-G589.

Sedlak J and Lindsay RH, 1968. Estimation of total, protein-bound, and nonprotein sulfhydryl groups in tissue with Ellman's reagent. Anal. Biochem. 25:192-205.

Seufi AM and Osman GE, 2005. Comparative susceptibility of the Egyptian cotton leafworm, $S$. littoralis to some Egyptian baculovirus isolates. Egypt. J. Biologic. Pest Control. 15:21-26.

Seufi AM, 2008. Characterization of an Egyptian $S$. littoralis nucleopolhedrovirus and a possible use of a highly conserved region from polyhedrin gene for nucleopolyhedrovirus detection. Virol. J. 5:13.

Shorey HH and Hale RL, 1965. Mass- rearing of the larvae of nine noctuid species on a simple artificial medium. J. Econ. Entomol. 58:522-524

Simpson DR, Bull DL and Linquist DA, 1964. A semimicrotechnique for estimation of cholinesterase activity in boll weevils. Ann. Entomol. Soc. Am. 57:367-371

Skehan P, Storeng R, Scudiero D, Monks A, McMahon J and Vistica D, 1990. New colorimetric cytotoxicity assay for anticancerdrug screening. J. Natl. Cancer Inst. 82(13): 1107-1112.

Stairs GR, 1965. Quantitative differences in susceptibility of nuclear polyhedrosis virus among larval instars of the forest tent caterpillar, Malacosoma dissteria (Hubner). J. Invert. Pathol. 7(4):427-429.

Sudhakar S, Varatharajan R and Mathavan S, 1997. Simple method to purify polyhedral inclusion bodies from Nosema (Microspora: Nosmatidae) contamination. Entomol. 22:89-93.

Sutanto KD, El-Salamouny S and Al-Dawood AS, 2014. Affectivity of Spodoptera littoralis nucleopolyhedrovirus (SpliNPV) against first and second instar larvae of the cotton leafworm, Spodoptera littoralis (Boisd.) (Lepidoptera: Noctuidae). Afr. J. Microbiol. Res. 8:337-340.

Szewczyk B, Hoyos-Carvajal L, Paluszek M, Skrzecz I and Lobo de Souza M, 2006. "Baculoviruses-re-emerging biopesticides". Biotechnol. Adv. 24:143-160.

Tanada Y and Kaya H, 1993. Systemic infection of nuclear polyhedrosis virus. Insect pathology, Academic Press lnc.ISBN 0-12-683255-2, San 
Diego, California, USA.

Todeschini V, Panini M, Chiesa O, Puggioni V, Anaclerio M, Vinsova H, Kamler M, Titfra D and Mazzoni E, 2017. In vitro study on the inhibition of enzymatic systems in Italian and Carniolan honey bees by piperonyl butoxide new derivatives. Bull. Insectol. 70(2): 237-244

Tsai YC, Wang YH and Liu YC, 2017. Overexpression of PCNA Attenuates Oxidative Stress-Caused Delay of Gap-Filling during Repair of UV-Induced DNA Damage. J. Nucleic Acids. 8154646.

Van Asperen K, 1962. A study of house fly esterase by means of sensitive colorimetric method. J. Insect Physiol. 8:401-416.

Vielhauer V and Mayadas TN, 2007. Functions of $\mathrm{TNF}$ and its receptors in renal disease: distinct roles in inflammatory tissue injury and immune regulation. Seminars in Nephrol. 27(3): 286-308.

Wilson KR, O'Reilly DR, Hails RS and Cory JS, 2000. Age-related effects of the Autographa californica multiple nucleopolyhedrovirus egt gene in the cabbage looper (Trichoplusia ni). Biol. Control. 19:57-63.

Wood HA, 1996. Genetically enhanced baculovirus insecticides. In "Molecular biology of the biological control of pest and diseases of plants" Edited by: Gunasekaran M, Weber DJ. CRC Press, Boca Raton 91-104.

Zhao M, Li S and Zhou Q, 2019. Safety evaluation of microbial pesticide (HaNPV) based on PCR method. Front. Chem. Sci. Eng. 13:377-384.

Zhu S, Zhao L, Fan Y, Lv Q, Wu K, Lang Z, Li Z, Yi $\mathrm{Z}$ and Geng D, 2020. Interaction between TNF- $\alpha$ and oxidative stress status in first-episode drugnaïve schizophrenia. Psychoneuroendocrinol. 114:104595.

\section{Contribution of Authors}

El Sayed YA: Designed, Performed the experiments, Collected and analyzed the data, and wrote original draft, Read and approved the manuscript, additionally performed isolation of virus and improvement of its efficacy against Spodoptera littoralis by using synergistic agents Ahmed RA: Designed, Performed the experiments, Collected and analyzed the data, and wrote original draft, Read and approved the manuscript, additionally performed histopathological biosafety studies Desoky SM: Designed, Performed the experiments, Collected and analyzed the data, and wrote original draft, Read and approved the manuscript, additionally performed isolation of virus and improvement of its efficacy against Spodoptera littoralis by using synergistic agents 